Supporting Information for:

\title{
Probing the Structural Requirements of Peptoids that Inhibit HDM2-p53 Interactions
}

\author{
Toshiaki Hara, ${ }^{9}$ Stewart R. Durell, ${ }^{\jmath}$ Michael C. Myers, ${ }^{\dagger}$ \\ and Daniel H. Appella* \\ ILaboratory of Cell Biology, NCI, NIH, DHHS, Bethesda, MD 20892 \\ 'Department of Chemistry, Northwestern University, Evanston, IL 60208 \\ ${ }^{\S}$ Laboratory of Bioorganic Chemistry, NIDDK, NIH, DHHS, Bethesda, MD 20892 \\ appellad@niddk.nih.gov
}

\section{Contents:}

1. References with more than 10 authors $\quad$ S2

2. Additional peptoid structures S3

3. General methods $\quad$ S5

4. Synthesis of Building blocks for peptoid synthesis S6

5. Peptoid synthesis and characterization $\quad \mathrm{S} 15$

6. HDM2 Preparation, CD, Fluorescence polarization Competition, $\begin{array}{ll}\text { ITC binding study, Analytical Ultracentrifugation } & \text { S17 }\end{array}$

$\begin{array}{lll}\text { 7. References } & \text { S19 }\end{array}$ 
References with excess of 10 authors:

10h. Grasberger, B. L.; Lu, T.; Schubert, C.; Parks, D. J.; Carver, T. E.; Koblish, H. K.; Cummings, M. D.; LaFrance, L.V.; Milkiewicz, K.L.; Calvo, R.R.; Maguire, D.;

Lattanze, J.; Franks, C.F.; Zhao, S.; Ramachandren, K.; Bylebyl, G.R.; Zhang, M.; Manthey, C.L.; Petrella, E.C.; Pantoliano, M.W.; Deckman, I.C.; Spurlino, J.C.; Maroney, A.C.; Tomczuk, B.E.; Molloy, C.J.; Bone, R.F. J. Med. Chem. 2005, 48, 909912.

10j. Ding, K.; Lu, Y.; Nikolovska-Coleska, Z.; Qiu, S.; Ding, Y.; Gao, W.; Stuckey, J.; Krajewski, K.; Roller, P.P.; Tomita, Y.; Parrish, D.A.; Deschamps, J.R.; Wang, S. J. Am. Chem. Soc. 2005, 127, 10130-10131.

12a. Zuckermann, R.N.; Martin, E.J.; Spellmeyer, D.C.; Stauber, G.B.; Shoemaker, K.R.; Kerr, J.M.; Figliozzi, G.M.; Goff, D.A.; Siani, M.A.; Simon, R.J.; Banville, S.C.; Brown, E.G.; Wang, L.; Richter, L.S.; Moos, W.H. J. Med. Chem. 1994, 37, 2678-2685.

12c. Planells-Cases, R.; Montoliu, C.; Humet, M.; Fernandez, A.M.; Garcia-Martinez, C.; Valera, E.; Merino, J.M.; Perez-Paya, E.; Messeguer, A.; Felipo, V.; Ferrer-Montiel, A. J. Pharmacol. Exp. Ther. 2002, 302, 163-173.

12d. Garcia-Martinez, C.; Humet, M.; Planells-Cases, R.; Gomis, A.; Caprini, M.; Viana, F.; De La Pena, E.; Sanchez-Baeza, F.; Carbonell, T.; De Felipe, C.; Perez-Paya, E.; Belmonte, C.; Messeguer, A.; Ferrer-Montiel, A. Proc. Natl. Acad. Sci. USA 2002, 99, 2374-2379.

17. Gibbons, J.A.; Hancock, A.A.; Vitt, C.R.; Knepper, S.; Buckner, S.A.; Brune, M.E.; Milicic, I.; Kerwin, J.F. Jr.; Richter, L.S.; Taylor, E.W.; Spear, K.L.; Zuckermann, R.N.; Spellmeyer, D.C.; Braeckman, R.A.; Moos, W.H. J. Pharmacol. Exp. Ther. 1996, 277, 885-899.

18. Vassilev, L.T.; Vu, B.T.; Graves, B.; Carvajal, D.; Podlaski, F.; Filipovic, Z.; Kong, N.; Kammlott, U.; Lukacs, C.; Klein, C.; Fotouhi, N.; Liu, E.A. Science 2004, 303, 844848.

19b. MacKerell, A.D.; Bashford, D.; Bellott, M.; Dunbrack, R.L.; Evanseck, J.D.; Field, M.J.; Fischer, S.; Gao, J.; Guo, H.; Ha, S.; Joseph-McCarthy, D.; Kuchnir, L.; Kuczera, K.; Lau, F.T.K.; Mattos, C.; Michnick, S.; Ngo, T.; Nguyen, D.T.; Prodhom, B.; Reiher, W.E.; Roux, B.; Schlenkrich, M.; Smith, J.C.; Stote, R.; Straub, J.; Watanabe, M.;

Wiorkiewicz-Kuczera, J.; Yin, D.; Karplus, M. J. Phys. Chem. B 1998, 102, 3586-3616.

23. Houtman, J.C.D.; Higashimoto, Y.; Dimasi, N.; Cho, S.W.; Yamaguchi, H.; Bowden, B.; Regan, C.; Malchiodi, E. L.; Mariuzza, R.; Schuck, P.; Appella, E. and Samelson, L. E. Biochemistry 2004, 43, 4170-4178. 


\section{Additional Peptoid Structures}

PS1. (Nspe) $)_{10}$ Insoluble in water, soluble in $\mathrm{CH}_{3} \mathrm{CN}, \mathrm{CD}$ shows helix

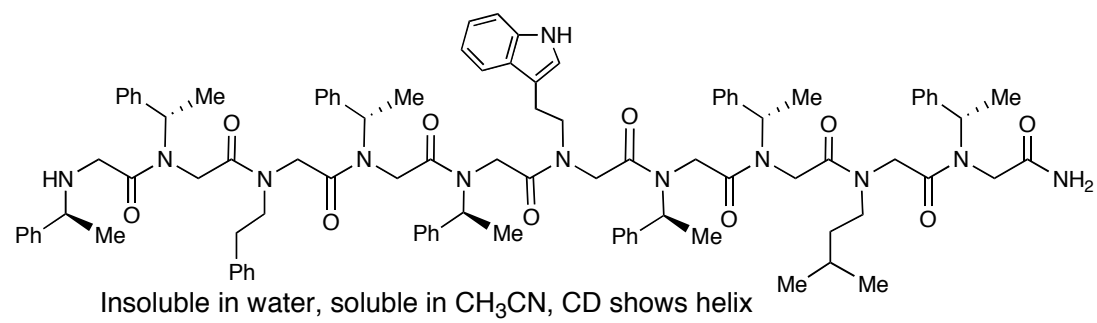

PS3.
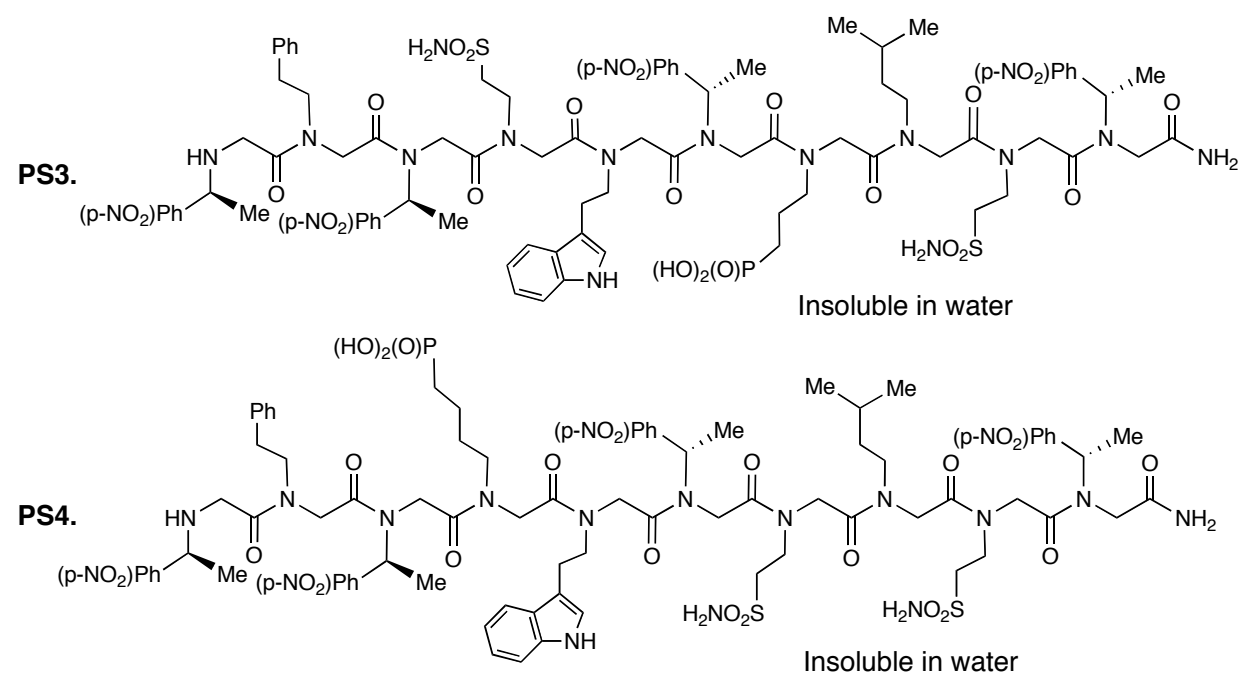

Figure S1. Peptoids to establish helicity and water solubility. 

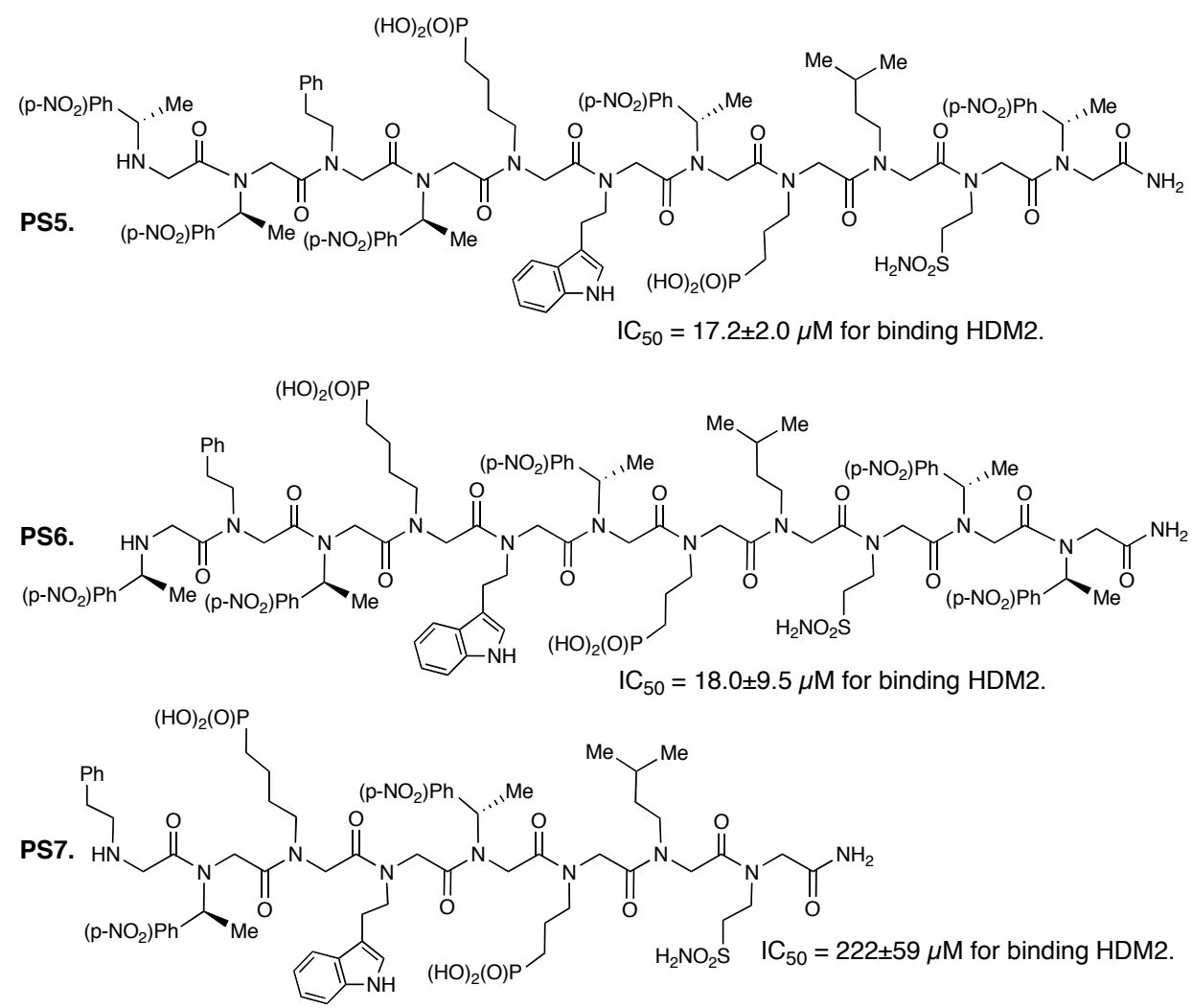

Figure S2. Peptoids that probe the dependence of length on HDM2 binding. All peptoids were water soluble.

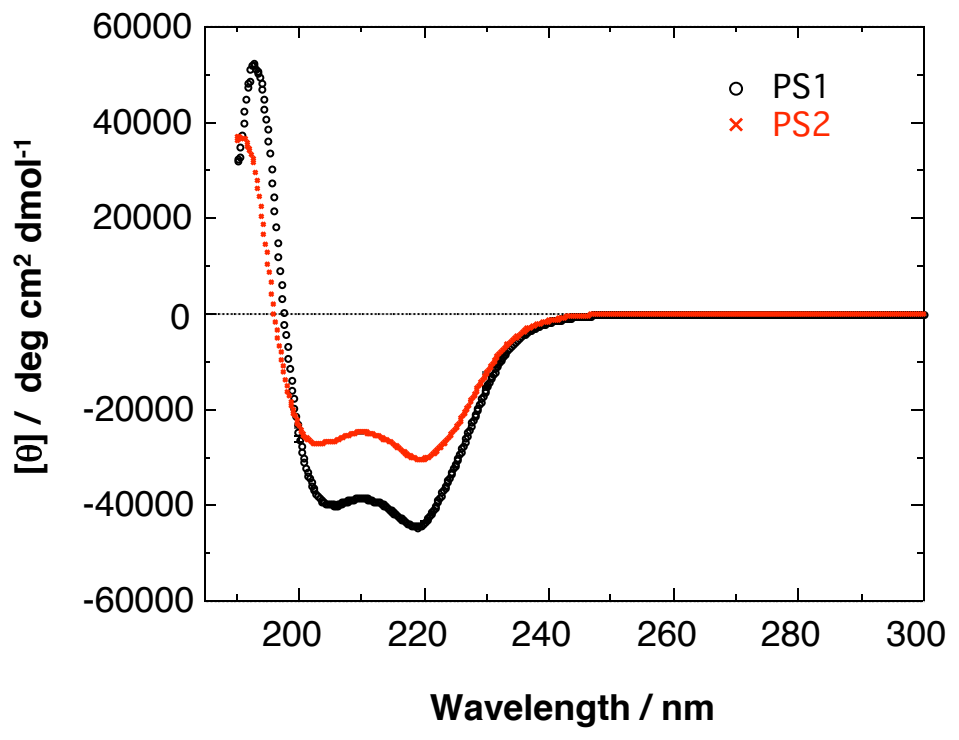

Figure S3. CD Spectra of Peptoids PS1 and PS2, measured in $\mathrm{CH}_{3} \mathrm{CN}$ at $60 \mu \mathrm{M}$ Peptoid concentration. 
Table 1. $\mathrm{IC}_{50}$ Values Obtained from Fluorescence Polarization

\begin{tabular}{cc}
\hline Peptoid & $\mathrm{IC}_{50}(\mu \mathrm{M})^{\mathrm{a}}$ \\
\hline PS1 & $\mathrm{ND}^{\mathrm{b}}$ \\
PS2 & $\mathrm{ND}^{\mathrm{b}}$ \\
PS3 & $\mathrm{ND}^{\mathrm{b}}$ \\
PS4 & $\mathrm{ND}^{\mathrm{b}}$ \\
PS5 & $17.2 \pm 2.0$ \\
PS6 & $18.0 \pm 9.5$ \\
PS7 & $222 \pm 59$ \\
\hline Concentration necessary to \\
displace 50\% of HDM-2 bound \\
Flu-p53(15-29). For comparison, \\
the p53(15-29) & peptide bound \\
with an IC & $=3.0 \pm 0.3 \mu \mathrm{M}$. \\
b ND = Not determined due to \\
poor aqueous solubility.
\end{tabular}

\section{Abbreviations:}

$\mathrm{Boc}_{2} \mathrm{O}$ : di-tert-butyl diacarbonate, $\mathrm{Cbz}$ : benzyloxycarbonyl, $\mathrm{CH}_{3} \mathrm{CN}$ : acetonitrile, $\mathrm{DCM}$ :Dichloromethane, DIEA: $\quad N, N$-diisopropylethylamine, $\quad$ DMAP: $\quad 4-$ (dimethylamino)pyridine, Fmoc: 9-fluorenylmethoxycarbonyl, NMP: N-methyl-2pyrrolidone, Phth: phthalimide, RBF: round bottom flask, TBTA: tert-butyl 2,2,2trichloroacetimidate, TEA: triethylamine, TFA: trifluoroacetic acid, THF: Tetrahydrofuran

Flu-p53(15-29) : N-terminal fluorescein-labeled p53 peptide containing residues 15-29, p53(15-29) : p53 peptide containing residues 15-29

ESI-MS: electrospray ionization mass spectrometry, MALDI-TOF-MS: matrix assisted laser desorption ionization/time-of-flight mass spectrometry, ${ }^{1} \mathrm{H}$ NMR: Proton nuclear magnetic resonance spectra, ${ }^{13} \mathrm{C}$ NMR: Carbon nuclear magnetic resonance spectra, ${ }^{31} \mathrm{P}$ NMR: Phosphorous nuclear magnetic resonance spectra

\section{General Methods}

All reactions (schemes 2-5) were performed in oven dry glassware under a positive pressure of argon unless otherwise noted. THF was distilled under $\mathrm{N}_{2}$ from sodium/benzophenone immediately before use. DCM was distilled from $\mathrm{P}_{2} \mathrm{O}_{5}$ and kept over $4 \AA$ molecular sieves. 4-Nitrobenzylamine hydrochloride, (S)- $\alpha$-Methyl-4nitrobenzylamine hydrochloride and $\mathrm{N}$-(4-bromobutyl)phtalimide were purchased from TCI America. (R)- $\alpha$-Methyl-4-nitrobenzylamine hydrochloride was a product of Fluka. $\beta$-Alanine-tert-butylester hydrochloride was obtained from Bachem. 6-Chloroindole was 
a product of Lancaster. $\mathrm{CH}_{3} \mathrm{CN}$ and NMP were purchased from American Biochemical. TentaGel Rink-amide resins (substitution $0.25-0.30 \mathrm{mmol} / \mathrm{g}$ ) were obtained from Peptides International. Unless otherwise noted, all other reagents and solvents were purchased from Aldrich and used without further purification.

Analytical thin-layer chromatography (TLC) was carried out on Whatman TLC plates precoated with silica gel 60 (250 $\mu$ m layer thickness). Visualization was accomplished using either a UV lamp, iodine and/or ninhydrin stain. Flash chromatography was performed on EM Science silica gel 60 (230-400 mesh). Solvent mixtures used for TLC and column chromatography are reported in $\mathrm{v} / \mathrm{v}$ ratios. Melting points (mp) were obtained on a Buchi 510 capillary melting point apparatus and are uncorrected.

${ }^{1} \mathrm{H}$ NMR spectra and ${ }^{13} \mathrm{C}$ NMR spectra were recorded at $300 \mathrm{MHz}$ and $75 \mathrm{MHz}$, respectively, on a Variant GEMINI-300 spectrometer, using $\mathrm{CDCl}_{3}$ or $\mathrm{d}_{6}$-DMSO as solven. Chemical shifts were reported in parts per million (ppm, $\delta$ ) relative to tetramethylsilane $(\delta 0.00) .{ }^{31} \mathrm{P}$ NMR spectra were recorded using a Variant XL-300 spectrometer $(121 \mathrm{~Hz})$, orthophosphoric acid $(85 \%)$ was used as an external standard. ${ }^{1} \mathrm{H},{ }^{13} \mathrm{C}$ and ${ }^{31} \mathrm{P}$ NMR splitting patterns are designated as singlet $(\mathrm{s})$, doublet $(\mathrm{d})$, triplet $(\mathrm{t})$, or quartet (q). All first-order splitting patterns were assigned on the basis of the appearance of the multiplet. Splitting patterns that could not be easily interpreted are designated as multiplet (m) or broad (br). Mass spectra were obtained using a Micromass TofSpec-2E spectrometer (MALDI-TOF-MS) with $\alpha$-cyano-4-hydroxy cinnamic acid as the matrix, acquired using a $\mathrm{N}_{2}$ laser (337 nm wavelength, 5ns pulse), with an average of 80 shots per sample, or a Hewlett Packard 1100 ESPRAY system (ESI-MS). Flu-p53(15$29)$ and p53(15-29) ${ }^{1}$ were prepared as reported previously. Nutlin-3a and 3b were obtained from Dr. Vassiliv at Hoffman LaRoche.

\section{Synthesis of Building blocks for peptoid synthesis}

\section{Scheme 1}
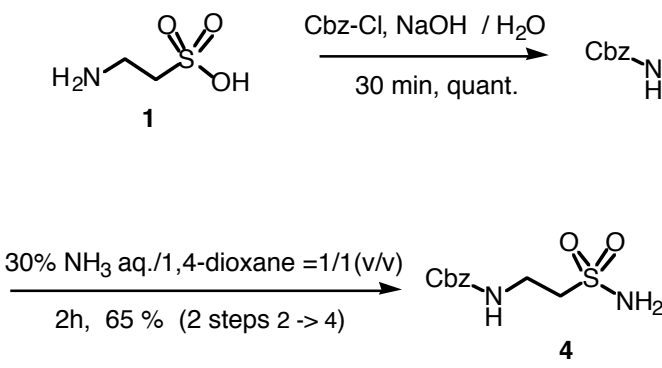

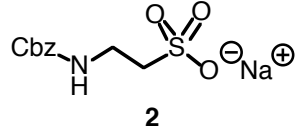

2

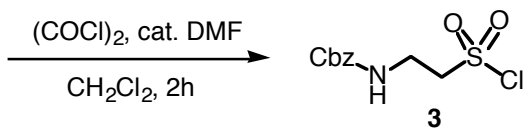

3

Cbz- $\boldsymbol{\beta}$-Aminoethanesulfonate sodium salt (2) and Cbz- $\boldsymbol{\beta}$-Aminoethanesulfonyl Chloride (3) : Compounds 2 and $\mathbf{3}$ were prepared according to the procedure described Brouwer and coworkers. ${ }^{2}$ Compound $\mathbf{3}$ was used immediately in the next reaction. 
Cbz- $\boldsymbol{\beta}$-Aminoethanesulfonamide (4) : Ammonium hydroxide $(29.6 \%$ aqueous solution, $70 \mathrm{~mL}$ ) and 1,4-dioxane $(70 \mathrm{~mL})$ was added to a $500 \mathrm{~mL} \mathrm{RBF}$ and cooled to 0 ${ }^{\circ} \mathrm{C}$ via an ice/water bath. Next, freshly prepared sulfonyl chloride $3(60 \mathrm{mmol})$ in dry $\mathrm{CH}_{3} \mathrm{CN}(20 \mathrm{~mL})$ was added dropwise to the reaction flask over $20 \mathrm{~min}$. The solution was stirred at $0{ }^{\circ} \mathrm{C}$ for $30 \mathrm{~min}$ and then warmed to rt, stirring an additional $1 \mathrm{~h}$. The solution was concentrated on a rotary evaporator. The resulting off-white crystalline residue was filtered and washed with water $(300 \mathrm{~mL})$, and dried under vaccum to give $10.9 \mathrm{~g}(65 \%$, over 2 steps from 2$)$ of $\mathbf{4}$ as white crystals. Rf: $0.71\left(\mathrm{CHCl}_{3} / \mathrm{MeOH} / \mathrm{AcOH}=80: 20: 1\right)$; mp: $133-134{ }^{\circ} \mathrm{C} ;{ }^{1} \mathbf{H}$ NMR: $\delta\left(300 \mathrm{MHz}, d_{6}\right.$-DMSO) $7.35(5 \mathrm{H}, \mathrm{m}, \mathrm{Ph}-\mathbf{H}), 6.90(2 \mathrm{H}, \mathrm{s}$, $\left.\mathrm{SO}_{2} \mathrm{NH}_{2}\right), 5.03\left(\mathrm{~s}, 2 \mathrm{H}, \mathrm{CH}_{2} \mathrm{Ph}\right), 3.45\left(2 \mathrm{H}, \mathrm{m}, \mathrm{NHCH}_{2}\right), 3.12\left(2 \mathrm{H}, \mathrm{m}, \mathrm{CH}_{2} \mathrm{SO}_{2}\right) ;{ }^{13} \mathbf{C}$ NMR: $\delta\left(75 \mathrm{MHz}, d_{\sigma}\right.$-DMSO) $156.0,137.0,128.4,127.9,127.8,65.5,53.9,35.7$; LRMS (ESIMS m/z): Calcd for $\mathrm{C}_{10} \mathrm{H}_{14} \mathrm{~N}_{2} \mathrm{NaO}_{4} \mathrm{~S}[\mathrm{M}+\mathrm{Na}]^{+}=281.1$; Found 281 .

$\beta$-Aminoethanesulfonamide hydrochloride salt (5) : Cbz- $\beta$-Aminoethanesulfonamide (4) $(15 \mathrm{~g}, 53.4 \mathrm{mmol})$ was added to a $2 \mathrm{~L} \mathrm{RBF}$ followed by $\mathrm{MeOH}(950 \mathrm{~mL}) .5 \% \mathrm{Pd} / \mathrm{C}$ $(10 \mathrm{~g})$ was added to the reaction mixture, then hydrogen is introduced to the solution by gas inlet tube with stirring for $15 \mathrm{~min}$. Then, formic acid $(50 \mathrm{~mL})$ was added to the reaction mixture and the solution was stirred an additional $10 \mathrm{~min}$. The reaction mixture was filtered, concentrated on a rotary evaporator. After azeotropically drying the resulting oil with toluene, diethyl ether $(70 \mathrm{~mL})$ and $4 \mathrm{M} \mathrm{HCl}$ diethyl ether $(70 \mathrm{~mL})$ was successively added to the oil and a white precipitate was formed. The precipitated was filtrated with glass fritted funnel and was washed with diethyl ether $(100 \mathrm{~mL})$ and dry under air to give a $8.2 \mathrm{~g}(96 \%)$ of $\mathbf{5}$ as a white crystal. Rf: $0.47\left(\mathrm{PrOH} / 29.6 \% \mathrm{NH}_{3}\right.$ aq/water $=9 / 1 / 2)$; mp: $132{ }^{\circ} \mathrm{C}($ dec. $) ;{ }^{1} \mathbf{H}$ NMR: $\delta\left(300 \mathrm{MHz}, d_{6}\right.$-DMSO) $8.23(3 \mathrm{H}, \mathrm{bs}$, $\left.\mathrm{NH}_{3} \mathbf{C l}\right), 7.20\left(2 \mathrm{H}, \mathrm{bs}, \mathrm{SO}_{2} \mathrm{NH}_{2}\right), 3.36\left(2 \mathrm{H}, \mathrm{m}, \mathrm{NHCH}_{2}\right), 3.15\left(2 \mathrm{H}, \mathrm{m}, \mathrm{CH}_{2} \mathrm{SO}_{2}\right) ;{ }^{13} \mathbf{C}$ NMR: $\delta\left(75 \mathrm{MHz}, d_{6}\right.$-DMSO) 51.6, 34.2; LRMS (ESI-MS m/z): Calcd for $\mathrm{C}_{2} \mathrm{H}_{9} \mathrm{~N}_{2} \mathrm{O}_{2} \mathrm{~S}$ $[\mathrm{M}+\mathrm{H}]^{+}=125.0$ and $\mathrm{C}_{4} \mathrm{H}_{12} \mathrm{~N}_{3} \mathrm{O}_{2} \mathrm{~S}\left[\mathrm{M}+\mathrm{H}+\mathrm{CH}_{3} \mathrm{CN}\right]^{+}=166.1$; Found $125.0(5 \%)$ and 166.1 (base peak)

\section{Scheme 2}
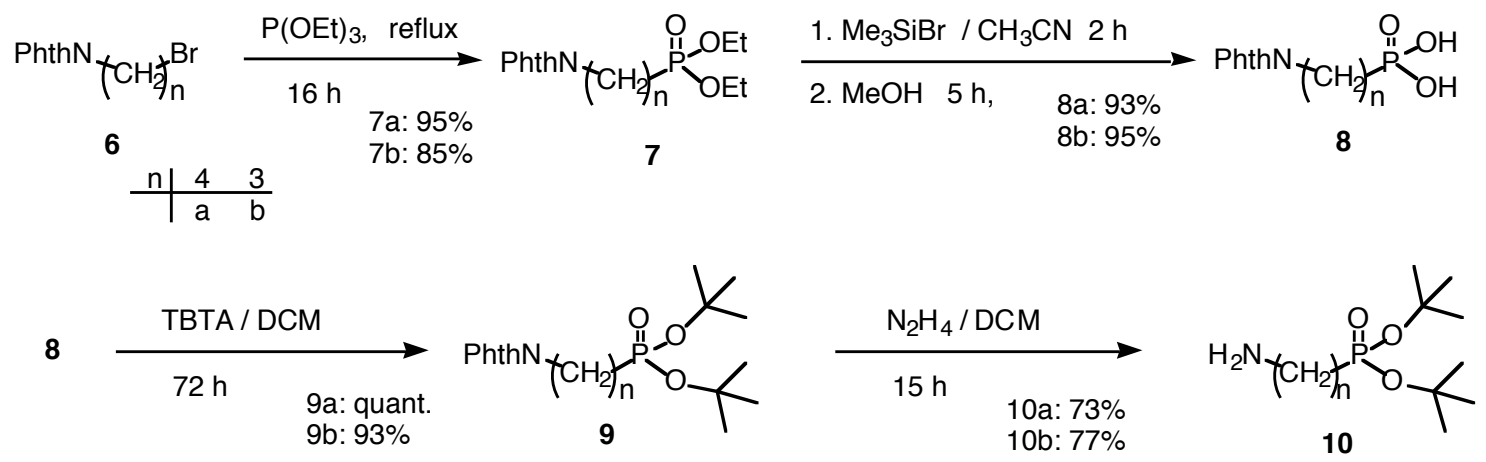

A preliminary account of this synthesis (scheme 2) was presented at the $229^{\text {th }}$ American Chemical Society Meeting, San Diego, CA, 2005. 
Di-Ethyl-4-phthalimidobutylphosphonates (7a) : $N$-(4-Bromobutyl)-phthalimide (6a) (35.3g, $125 \mathrm{mmol}, 1$ equiv.) and triethyl phosphite $(214 \mathrm{~mL}, 1.25 \mathrm{~mol}, 10$ equiv.) were added to a $500 \mathrm{~mL} \mathrm{RBF}$ at rt. The solution was refluxed (external temperature at 160$170^{\circ} \mathrm{C}$ ) for $16 \mathrm{~h}$ (Note: this reaction was performed open to the ambient atmosphere). Volatile products were distilled off in vacuo to afford the crude product as a faint yellow viscous oil which crystallized at rt. The faint yellow crystals were washed heptane (100 $\mathrm{mL})$ to give $40.3 \mathrm{~g}(118 \mathrm{mmol}, 95 \%)$ of $\mathbf{7 a}$ as a white solid. Rf: 0.38 (EtOAc); mp: 134-136 ${ }^{\circ} \mathrm{C}$; ${ }^{1} \mathrm{H}$ and ${ }^{13} \mathrm{C}$ NMR data were consistent with the literature data for this compound. ${ }^{3}$

Di-Ethyl-3-phthalimidopropylphosphonates (7b) : Crude compound 7b was obtained according to the procedure to make 7a. The crude product (a yellow viscous oil) was purified by silica gel column (Hexanes/EtOAc $=1 / 5$ then EtOAc/EtOH $=95 / 5)$ to give 28 $\mathrm{g}(86 \mathrm{mmol}, 85 \%)$ of $\mathbf{7 b}$ as a colorless oil. Rf: 0.31 (EtOAc); ${ }^{1} \mathrm{H}$ and ${ }^{13} \mathrm{C}$ NMR data were consistent with the literature data for this compound. ${ }^{3}$

4-Phthalimidobutylphosphonic acid (8a) : Di-Ethyl-4-phthalimidobutylphosphonate 7a $\left(20 \mathrm{~g}, 60 \mathrm{mmol}, 1\right.$ equiv.) and dry $\mathrm{CH}_{3} \mathrm{CN}(120 \mathrm{~mL})$ were added to a $500 \mathrm{~mL}$ RBF. The resulting solution was cooled to $0{ }^{\circ} \mathrm{C}$ via an ice bath and Trimethylsilyl bromide (16.3 mL, $126 \mathrm{mmol}, 2.1$ equiv.) was added dropwise over $5 \mathrm{~min}$. The ice bath was removed and the solution allowed to warm to $\mathrm{rt}$. After $3 \mathrm{~h}$ of stirring, the reaction was quenched with a slow addition of $\mathrm{MeOH}(30 \mathrm{~mL})$ and the solution was stirred for an additional $3 \mathrm{~h}$. The volatile material was removed under reduced pressure. The residue was dissolved in EtOAc $(50 \mathrm{~mL})$ and then $\mathrm{H}_{2} \mathrm{O}(10 \mathrm{~mL})$ was added. The mixture was stirred for $4 \mathrm{~h}$ and a white precipitate formed. The precipitate was filtrated with a glass fritted funnel and died under vacuum, and washed with diethyl ether $(3 \times 30 \mathrm{~mL})$. The solid was dried in vacuo to give $15.8 \mathrm{~g}$ (55.9 mmol, 93.2\% yield) of 8a as a white solid. Rf: 0.20 (2-Propanol/30\% $\left.\mathrm{NH}_{3} \mathrm{aq} / \mathrm{H}_{2} \mathrm{O}=9: 1: 2\right)$; mp: $159-160{ }^{\circ} \mathrm{C} ;{ }^{1} \mathbf{H}$ NMR: $\delta(300 \mathrm{MHz}$, $d_{6}$-DMSO) 7.89-7.82 (4H, m, Ph-H), $3.57\left(2 \mathrm{H}, \mathrm{t}, J=6.9 \mathrm{~Hz}, \mathrm{NCH}_{2}\right), 1.67(2 \mathrm{H}, \mathrm{m}$, $\left.\mathrm{NCH}_{2} \mathrm{CH}_{2}\right), 1.62-1.41\left(4 \mathrm{H}, \mathrm{m}, \mathrm{CH}_{2} \mathrm{CH}_{2} \mathrm{P}\right) ;{ }^{13} \mathbf{C}$ NMR: $\delta\left(75 \mathrm{MHz}, d_{6}\right.$-DMSO) 168.0, 134.6, 131.7, 123.0, 37.1, 29.0 (d, $J=15.5 \mathrm{~Hz}), 27.1$ (d, $J=136.3 \mathrm{~Hz}), 20.3(\mathrm{~d}, J=4.5$ $\mathrm{Hz}$ ); LRMS (ESI-MS m/z): Calcd for $\mathrm{C}_{12} \mathrm{H}_{13} \mathrm{NO}_{5} \mathrm{P}[\mathrm{M}-\mathrm{H}]^{-}=282.1$; Found 282.

3-Phthalimidopropylphosphonic acid (8b) : Prepared as described for 8a to give the product as white crystals (14.2 g, $23.3 \mathrm{mmol}$, 95\% yield). Rf: 0.20 (2-Propanol/30\% $\mathrm{NH}_{3}$ aq/ $\left.\mathrm{H}_{2} \mathrm{O}=9: 1: 2\right)$; mp: $179-182{ }^{\circ} \mathrm{C} ;{ }^{1} \mathbf{H}$ NMR: $\delta\left(300 \mathrm{MHz}, d_{6}\right.$-DMSO) 7.89-7.81 (4H, m, Ph-H), $3.61(2 \mathrm{H}, \mathrm{t}, J=7.1 \mathrm{~Hz}), 1.82-1.73(2 \mathrm{H}, \mathrm{m}), 1.58-1.47(2 \mathrm{H}, \mathrm{m}) ;{ }^{13} \mathrm{C}$ NMR: $\delta(75$ $\mathrm{MHz}, d_{6}$-DMSO) 168.0, 134.4, 131.7, 123.0, $38.2(\mathrm{~d}, J=20 \mathrm{~Hz}), 25.2(\mathrm{~d}, J=137.4 \mathrm{~Hz})$, 22.1(d, $J=4.0 \mathrm{~Hz}$ ); LRMS (ESI-MS m/z): Calcd for $\mathrm{C}_{11} \mathrm{H}_{11} \mathrm{NO}_{5} \mathrm{P}[\mathrm{M}-\mathrm{H}]^{-}=268.0$; Found 268.

Di-tert-butyl 4-phthalimidobutylphosphonate (9a) : 4-phthalimidobutylphosphonic 
acid (8a) $(7.1 \mathrm{~g}, 25 \mathrm{mmol})$ was added to a $250 \mathrm{~mL}$ of RBF followed by DCM (70 $\mathrm{mL})$ and cooled to $0{ }^{\circ} \mathrm{C}$ via an ice/water bath. Next, TBTA (16.4g, $75 \mathrm{mmol}, 3$ equiv.) which was prepared according to the procedure described Armstrong $\mathrm{A}$ et $\mathrm{al},{ }^{4}$ was added to the reaction flask, and the reaction was stirred for $30 \mathrm{~min}$ at $0{ }^{\circ} \mathrm{C}$, then the ice/water bath was removed. The reaction stirred for an additional $12 \mathrm{~h}$ at $\mathrm{rt}$. Additional TBTA $(27.3 \mathrm{~g}, 125$ mmol, 5 equiv.) was added to the reaction flask in 3 equal portions over $24 \mathrm{~h}$ (1 portion per $12 \mathrm{~h}$ ) at rt. After complete addition of TBTA, the reaction was allowed to stir an additional $24 \mathrm{~h}$. Precipitated trichloroacetamide was filtered off and the filtrate was evaporated in vacuo. The residue was taken up in hexane and filtered. Then, the filtrate was evapolated in vacuo and the residue was taken up in EtOAc $(100 \mathrm{~mL})$, washed with $0.5 \mathrm{M} \mathrm{NaHCO}_{3}$ (aq.) $(2 \times 330 \mathrm{~mL})$ then $\mathrm{NaCl}$ (sat. aq.) $(30 \mathrm{~mL})$. The organic layer was dried over $\mathrm{Na}_{2} \mathrm{SO}_{4}$, and concentrated to give a crude faint yellow oil which was purified by a short silica gel column (Hexanes/EtOAc $=1 / 2$ then EtOAc/EtOH $=95 / 5)$ to give $9.90 \mathrm{~g}$ ( $25 \mathrm{mmol}, 100 \%$ yield $)$ of $\mathbf{9 a}$ as a colorless oil which crystallized on storage. Rf: 0.24 (Hexane/EtOAc=2:5); mp: 87-89 ${ }^{\circ} \mathrm{C} ;{ }^{1} \mathbf{H}$ NMR: $\delta\left(300 \mathrm{MHz}, \mathrm{CDCl}_{3}\right) 7.88-7.82$ $(2 \mathrm{H}, \mathrm{m}, \mathrm{Ph}-\mathbf{H}), 7.75-7.69$ (2H, m, Ph-H), $3.69\left(2 \mathrm{H}, \mathrm{t}, J=7.1 \mathrm{~Hz}, \mathrm{NCH}_{2}\right), 1.80-1.60(6 \mathrm{H}$, $\left.\mathrm{m},\left(\mathrm{CH}_{2}\right)_{3} \mathrm{P}\right), 1.48\left(18 \mathrm{H}, \mathrm{s}, t-\mathrm{Bu}-\mathrm{CH}_{3}\right) ;{ }^{13} \mathbf{C} \mathbf{N M R}: \delta\left(75 \mathrm{MHz}, \mathrm{CDCl}_{3}\right)$ 168.5, 134.1, 132.3, 123.4, 81.6(d, $J=8.6 \mathrm{~Hz}), 37.7,30.6$ (d, $J=4.0 \mathrm{~Hz}), 29.9(\mathrm{~d}, J=146.1 \mathrm{~Hz}), 29.5$ $(\mathrm{d}, J=16.6 \mathrm{~Hz}), 21.1(\mathrm{~d}, J=5.7 \mathrm{~Hz}) ;{ }^{31}$ P NMR: $\delta\left(121 \mathrm{MHz}, \mathrm{CDCl}_{3}\right) 23.5$; LRMS (ESIMS m/z): Mass calcd for $\mathrm{C}_{12} \mathrm{H}_{15} \mathrm{NO}_{5} \mathrm{P}[\mathrm{M}(-2 \mathrm{tBu})+\mathrm{H}]^{+}=284.1, \mathrm{C}_{16} \mathrm{H}_{23} \mathrm{NO}_{5} \mathrm{P}[\mathrm{M}(-$ $\mathrm{tBu})+\mathrm{H}]^{+}=340.1, \mathrm{C}_{20} \mathrm{H}_{31} \mathrm{NO}_{5} \mathrm{P}[\mathrm{M}+\mathrm{H}]^{+}=396.2, \mathrm{C}_{20} \mathrm{H}_{30} \mathrm{NNaO}_{5} \mathrm{P}[\mathrm{M}+\mathrm{Na}]^{+}=418.2$; Found 284(base peak), 340(10\%), 396(30\%), 418(15\%).

\section{Di-tert-butyl 3-phthalimidopropylphosphonate (9b)}

Prepared as described for 9a to give the product as colorless crystals $(8.91 \mathrm{~g}, 23.3 \mathrm{mmol}$, 93\% yield). Rf: 0.27 (Hexane/EtOAc=2:5); mp: 64-66 ${ }^{\circ} \mathrm{C} ;{ }^{1} \mathbf{H}$ NMR: $\delta(300 \mathrm{MHz}$, $\left.\mathrm{CDCl}_{3}\right)$ 7.88-7.82 (2H, m, Ph-H), 7.75-7.69 (2H, m, Ph-H), $3.74(2 \mathrm{H}, \mathrm{t}, J=7.2 \mathrm{~Hz}$, $\mathrm{NCH}_{2}$ ), 2.10-1.88 and 1.74-1.63 (2H and $\left.2 \mathrm{H}, \mathrm{m}, \mathrm{CH}_{2} \mathrm{CH}_{2} \mathrm{P}\right), 1.49$ (18H, s, $t$-Bu-CH$)$; ${ }^{13}$ C NMR: $\delta\left(75 \mathrm{MHz}, \mathrm{CDCl}_{3}\right) 168.5,134.2,132.3,123.4,81.9(\mathrm{~d}, J=8.6 \mathrm{~Hz}), 38.6(\mathrm{~d}, J$ $=20.0 \mathrm{~Hz}), 30.6(\mathrm{~d}, J=4.0 \mathrm{~Hz}), 27.9(\mathrm{~d}, J=147.2 \mathrm{~Hz}), 23.1(\mathrm{~d}, J=5.7 \mathrm{~Hz}) ;{ }^{31} \mathbf{P}$ NMR: $\delta$ $\left(121 \mathrm{MHz}, \mathrm{CDCl}_{3}\right)$ 22.5; LRMS (ESI-MS m/z): Calcd for $\mathrm{C}_{11} \mathrm{H}_{13} \mathrm{NO}_{5} \mathrm{P}[\mathrm{M}(-2 \mathrm{tBu})+\mathrm{H}]^{+}=$ $270.1, \mathrm{C}_{15} \mathrm{H}_{21} \mathrm{NO}_{5} \mathrm{P}[\mathrm{M}(-\mathrm{tBu})+\mathrm{H}]^{+}=326.1, \mathrm{C}_{19} \mathrm{H}_{29} \mathrm{NO}_{5} \mathrm{P}[\mathrm{M}+\mathrm{H}]^{+}=382.2, \mathrm{C}_{19} \mathrm{H}_{28} \mathrm{NNaO}_{5} \mathrm{P}$ $[\mathrm{M}+\mathrm{Na}]^{+}=404.2$; Found 270(base peak), 326(10\%), 382(25\%), 404(10\%)

\section{Di-tert-butyl 4-aminobutylphosphonate (10a): $\quad$ Di-tert-butyl 4-} phthalimidobutylphosphonate 9a (5g, $12.6 \mathrm{mmol}, 1$ equiv.) was placed in a $500 \mathrm{~mL}$ RBF and followed by DCM $(150 \mathrm{~mL})$. Anhydrous hydrazine was added to the reaction flask and the solution was stirred for $15 \mathrm{~h}$. The resulting precipitate was filtered using a glass fritted funnel, washed with hexane $(50 \mathrm{~mL})$, and the filtrate was concentrated to give an oil with two layers. The oil was transferred to a separatory funnel with EtOAc $(50 \mathrm{~mL})$ and the organic layer was washed with $0.5 \mathrm{M} \mathrm{K}_{2} \mathrm{CO}_{3}(5 \times 25 \mathrm{~mL})$, saturated $\mathrm{NaCl}(50$ $\mathrm{mL})$ and $0.1 \mathrm{M} \mathrm{KHSO}_{4}(3 \times 25 \mathrm{~mL})$. The combined $0.1 \mathrm{M} \mathrm{KHSO}_{4}$ layer was basified to $\mathrm{pH} 8.5$ with $2 \mathrm{M}$ aqueous $\mathrm{K}_{2} \mathrm{CO}_{3}$ and extracted with EtOAc $(8 \times 25 \mathrm{~mL})$. The organic layer was dried over $\mathrm{Na}_{2} \mathrm{SO}_{4}$, filtrated, and concentrated using rotary evaporator to give a 
$2.44 \mathrm{~g} \quad(9.2 \mathrm{mmol}, 73 \%)$ of $\mathbf{1 0 a}$ as a faint yellow oil. Rf:0.52 (n$\mathrm{BuOH} / \mathrm{AcOH} / \mathrm{H} 2 \mathrm{O}=4: 1: 1)$; ${ }^{1} \mathbf{H}$ NMR: $\delta\left(300 \mathrm{MHz}, \mathrm{CDCl}_{3}\right) 2.72\left(2 \mathrm{H}\right.$, bs, $\left.\mathrm{NH}_{2}\right), 1.70$ $1.49(\mathrm{~m}) ;{ }^{13} \mathbf{C}$ NMR: $\delta\left(75 \mathrm{MHz}, \mathrm{CDCl}_{3}\right) 81.8(\mathrm{~d}, J=8.6 \mathrm{~Hz}), 42.2,35.1(\mathrm{~d}, J=15.5 \mathrm{~Hz})$, $30.9(\mathrm{~d}, J=4.0 \mathrm{~Hz}), 30.6(\mathrm{~d}, J=145.4 \mathrm{~Hz}), 21.3(\mathrm{~d}, J=5.7 \mathrm{~Hz}) ;{ }^{31} \mathbf{P}$ NMR: $\delta(121 \mathrm{MHz}$, $\mathrm{CDCl}_{3}$ ) 24.1; LRMS (ESI-MS m/z): Calcd for $\mathrm{C}_{12} \mathrm{H}_{29} \mathrm{NO}_{3} \mathrm{P}[\mathrm{M}+\mathrm{H}]^{+}=266.2$; Found 266.2

Di-tert-butyl 3-aminopropylphosphonate (10b) : Prepared as described for 10a to give the product as a faint yellow oil $(3.0 \mathrm{~g}, 12 \mathrm{mmol}, 77 \%)$. Rf: 0.48 (n$\mathrm{BuOH} / \mathrm{AcOH} / \mathrm{H} 2 \mathrm{O}=4: 1: 1) ;{ }^{1} \mathbf{H}$ NMR: $\delta\left(300 \mathrm{MHz}, \mathrm{CDCl}_{3}\right) 2.77\left(2 \mathrm{H}, \mathrm{bs}, \mathrm{NH}_{2}\right), 1.77-$ $1.63\left(6 \mathrm{H}, \mathrm{m},\left(\mathrm{CH}_{2}\right)_{3} \mathrm{P}\right), 1.50\left(18 \mathrm{H}, \mathrm{s}, \mathrm{t}-\mathrm{Bu}-\mathrm{CH}_{3}\right) ;{ }^{13} \mathbf{C}$ NMR: $\delta\left(75 \mathrm{MHz}, d_{6}\right.$-DMSO) 80.3 $(\mathrm{d}, J=8.0 \mathrm{~Hz}), 42.0(\mathrm{~d}, J=18.3 \mathrm{~Hz}), 30.0(\mathrm{~d}, J=4.0 \mathrm{~Hz}), 27.3(\mathrm{~d}, J=145.4 \mathrm{~Hz})$, 27.1(bs); ${ }^{31} \mathbf{P}$ NMR: $\delta$ (121 MHz, CDCl3) 24.1; LRMS (ESI-MS m/z): Calcd for $\mathrm{C}_{11} \mathrm{H}_{27} \mathrm{NO}_{3} \mathrm{P}[\mathrm{M}+\mathrm{H}]^{+}=252.2 ;$ Found 252.2 


\section{Scheme 3}

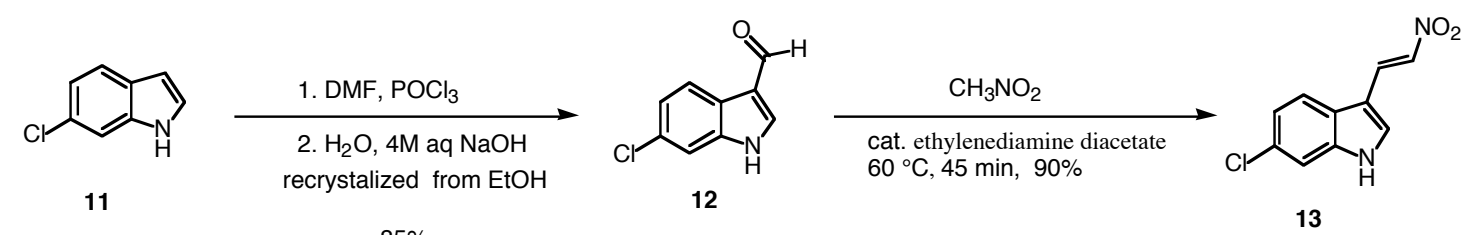

$85 \%$

13

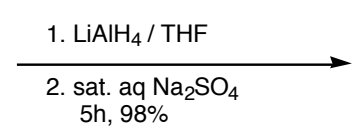

15

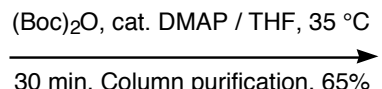

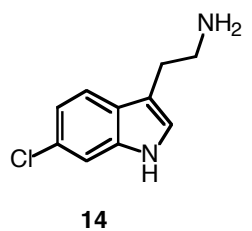

14

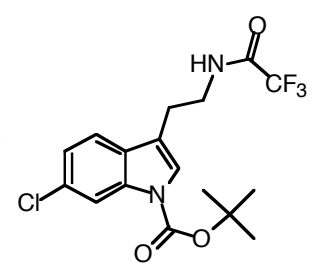

16

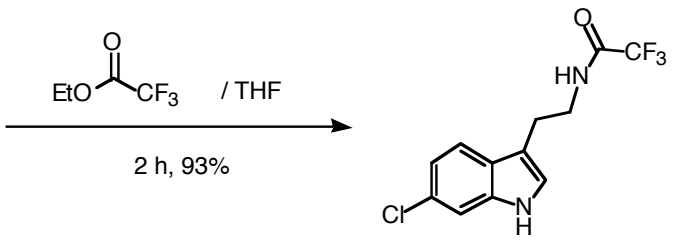

15

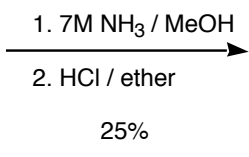

$25 \%$

17

Compounds 12-14 were synthesized using a modification of the procedure described by Whittle and coworkers. ${ }^{5}$

6-Chloroindole-3-carboxaldehyde (12): DMF (60 mL) was added into a $500 \mathrm{~mL}$ RBF and was cooled to $0{ }^{\circ} \mathrm{C}$ via an ice/water bath. Phosphorus oxychloride $(17.8 \mathrm{~mL}, 195$ mmol, 1.3 equiv.) was added dropwise to the RBF over 10 min. The solution was stirred an additional $40 \mathrm{~min}$ at $0{ }^{\circ} \mathrm{C}$. Next, 6-Chloroindole 11 (22.7 g, $150 \mathrm{mmol}, 1$ equiv.) was added to an another $250 \mathrm{~mL} \mathrm{RBF}$ followed by DMF $(145 \mathrm{~mL})$. The resultant solution was cooled to $0{ }^{\circ} \mathrm{C}$ via an ice/water bath. The solution containing 11 was cannula transferred to the solution containing phosphorus oxychloride over a 40 min period. The solution was stirred an additional $15 \mathrm{~min}$ at $0{ }^{\circ} \mathrm{C}$ and was allowed to warm to $\mathrm{rt}$ and stirred an additional $2 \mathrm{~h}$. Then, the whole reaction was added to cold water with stirring and the solution was neutralized with $4 \mathrm{M}$ aqueous $\mathrm{NaOH}(\mathrm{pH} 7.3)$. The resulting mixture was filtered using a glass fritted funnel, the solid collected was washed with $\mathrm{H}_{2} \mathrm{O}$ $(250 \mathrm{~mL})$ and dried under vacuum. The crude product was recrystalized from EtOH to give $22.9 \mathrm{~g}(85 \%)$ of $\mathbf{1 2}$ as a yellow crystal. Rf: 0.24 (Hexane/EtOAc=2:1); mp: 210$211{ }^{\circ} \mathrm{C}$, (lit. $\left.206^{\circ} \mathrm{C}^{5}\right) ;{ }^{1} \mathbf{H}$ NMR: $\delta\left(300 \mathrm{MHz}, d_{\sigma}\right.$-DMSO) $12.2(1 \mathrm{H}, \mathrm{bs}, \mathrm{NH}), 9.93(1 \mathrm{H}, \mathrm{s}$, CHO), 8.33(1H, s, $\left.\mathrm{C}_{2} \mathbf{H}\right), 8.07\left(1 \mathrm{H}, \mathrm{d}, J=8.6 \mathrm{~Hz}, \mathrm{C}_{4} \mathbf{H}\right), 7.57\left(1 \mathrm{H}, \mathrm{d}, J=1.9 \mathrm{~Hz}, \mathrm{C}_{7} \mathbf{H}\right)$, $7.24\left(1 \mathrm{H}, \mathrm{dd}, J=1.9 \mathrm{~Hz}, J=8.6 \mathrm{~Hz}, \mathrm{C}_{5} \mathbf{H}\right) ;{ }^{13} \mathbf{C}$ NMR: $\delta\left(75 \mathrm{MHz}, d_{6}\right.$-DMSO) 185.1, 139.3, 137.5, 127.9, 122.9, 122.5, 122.1, 118.0, 112.2; LRMS (ESI-MS m/z): Calcd for $\mathrm{C}_{9} \mathrm{H}_{7} \mathrm{ClNO}[\mathrm{M}+\mathrm{H}]^{+}=180.0$; Found 180.0 
3-[(E)-2-Nitroethenyl]-6-chloroindole (13) : 6-Chloroindole-3-carboxaldehyde 12 (10 $\mathrm{g}, 56 \mathrm{mmol}, 1$ equiv.) was added to a $100 \mathrm{~mL}$ of $\mathrm{RBF}$ followed by nitromethane $(46 \mathrm{~mL}$, $840 \mathrm{mmol}, 15$ equiv.) and ethylenediamine diacetate (1.5 g, $8.4 \mathrm{mmol}, 0.15$ equiv.), and warmed to $60-65{ }^{\circ} \mathrm{C}$ via a oil bath (Note: this reaction was performed open to the ambient atmosphere). The reaction stirred for an additional $45 \mathrm{~min}$ at $60-65{ }^{\circ} \mathrm{C}$. Then, the oil bath was removed and the reaction stood for $4 \mathrm{~h}$ at rt. The resulting yellow precipitate was filtered using a glass fritted funnel, washed with hot $\mathrm{H}_{2} \mathrm{O}(2 \times 25 \mathrm{~mL})$ and dried under vacuum to give $12.4 \mathrm{~g}(90 \%)$ of $\mathbf{1 3}$ as a yellow solid. Rf: 0.24 (Hexane/EtOAc=2:1); mp: $209{ }^{\circ} \mathrm{C}$ (dec.); ${ }^{1} \mathbf{H}$ NMR: $\delta\left(300 \mathrm{MHz}, d_{6}\right.$-DMSO) $12.2(1 \mathrm{H}$, bs, NH), $8.39\left(1 \mathrm{H}, \mathrm{d}, J=13.5 \mathrm{~Hz}, \mathrm{CH}=\mathrm{CH}-\mathrm{NO}_{2}\right), 8.03(1 \mathrm{H}, \mathrm{d}, J=13.5 \mathrm{~Hz}, \mathrm{CH}=\mathrm{CH}-$ $\left.\mathrm{NO}_{2}\right), 8.27\left(1 \mathrm{H}, \mathrm{s}, \mathrm{inC}_{2} \mathbf{H}\right), 8.02\left(1 \mathrm{H}, \mathrm{d}, J=8.6 \mathrm{~Hz}, \operatorname{inC}_{4} \mathbf{H}\right), 7.58(1 \mathrm{H}, \mathrm{d}, J=1.9 \mathrm{~Hz}$, $\left.\operatorname{inC}_{7} \mathbf{H}\right), 7.23\left(1 \mathrm{H}, \mathrm{dd}, J=1.9,8.6 \mathrm{~Hz}, \mathrm{inC}_{5} \mathbf{H}\right) ;{ }^{13} \mathbf{C ~ N M R : ~} \delta$ (75 MHz, $d_{6}$-DMSO) 138.1, 136.8, 134.0, 131.9, 127.9, 123.4, 121.9, 121.5, 112.5, 108.2; LRMS (ESI-MS m/z): Calcd for $\mathrm{C}_{10} \mathrm{H}_{8} \mathrm{ClN}_{2} \mathrm{O}_{2}[\mathrm{M}+\mathrm{H}]^{+}=223.0$; Found 223.0

6-Chlorotryptamine (14): Nitro-indole olefin 13 (13.4 g, $60 \mathrm{mmol}, 1$ equiv.) was added to a $1 \mathrm{~L} \mathrm{RBF}$ followed by THF $(200 \mathrm{~mL})$. The resulting solution was cooled to $0{ }^{\circ} \mathrm{C}$ via an ice/water bath. A $1 \mathrm{M}$ solution of $\mathrm{LiAlH}_{4}$ in THF $(300 \mathrm{~mL}, 300 \mathrm{mmol}, 5$ equiv.) was also cooled to $0{ }^{\circ} \mathrm{C}$ via an ice/water bath. The solution containing nitro-indole olefin $\mathbf{1 3}$ was cannula transferred to the solution containing $\mathrm{LiAlH}_{4}$ over a $1 \mathrm{~h}$ period. The solution was stirred an additional $30 \mathrm{~min}$ at $0{ }^{\circ} \mathrm{C}$ and was allowed to warm to $\mathrm{rt}$ and stirred an additional $4.5 \mathrm{~h}$. After this time, the reaction flask was cooled to $0{ }^{\circ} \mathrm{C}$ and quenched slowly with saturated solution of $\mathrm{Na}_{2} \mathrm{SO}_{4}$ in $\mathrm{H}_{2} \mathrm{O}(50 \mathrm{~mL})$. The solution formed a white solid that was allowed to stir an additional $30 \mathrm{~min}$ while warming back to $\mathrm{rt}$. The resulting suspended alminum salts were filtered off using a glass fritted funnel, washed with diethyl ether $(250 \mathrm{~mL})$, and the filtrate was concentrated to give $11.4 \mathrm{~g}(98 \%)$ of 14 as a tan oil, which crystallized while drying under vacuum. Rf: 0.46 (n$\left.\mathrm{BuOH} / \mathrm{AcOH} / \mathrm{H}_{2} \mathrm{O}=4: 1: 1\right)$; mp: $93-105{ }^{\circ} \mathrm{C} ;{ }^{1} \mathbf{H}$ NMR: $\delta\left(300 \mathrm{MHz}, \mathrm{CDCl}_{3}\right) 8.16(1 \mathrm{H}, \mathrm{bs}$, NH), $7.51(1 \mathrm{H}, \mathrm{d}, J=8.4 \mathrm{~Hz}, \mathrm{Ar}), 7.36(1 \mathrm{H}, \mathrm{d}, J=1.8 \mathrm{~Hz}, \mathrm{Ar}), 7.08(1 \mathrm{H}, \mathrm{dd}, J=8.4,1.8$ $\mathrm{Hz}, \mathrm{Ar}), 7.02(1 \mathrm{H}, \mathrm{s}), 3.02\left(2 \mathrm{H}, \mathrm{td}, J=6.6,0.9 \mathrm{~Hz}, \mathrm{CH}_{2} \mathrm{~N}\right), 2.88(2 \mathrm{H}, \mathrm{t}, J=6.6 \mathrm{~Hz}$, $\left.\mathrm{CH}_{2} \mathrm{CH}_{2} \mathrm{~N}\right), 1.40\left(2 \mathrm{H}\right.$, bs, $\left.\mathrm{NH}_{2}\right) ;{ }^{13} \mathbf{C}$ NMR: $\delta\left(75 \mathrm{MHz}, \mathrm{CDCl}_{3}\right)$ 137.0, 128.0, 126.3, 123.0, 120.0, 119.8, 113.8, 111.3, 42.4, 29.4; LRMS (ESI-MS m/z): Calcd for $\mathrm{C}_{10} \mathrm{H}_{12} \mathrm{ClN}_{2}[\mathrm{M}+\mathrm{H}]^{+}=195.1$; Found 195.1

$N$-Trifluoroacetyl-6-Chlorotryptamine (15): 6-Chlorotryptamine 14 (8.52 g, 43.8 mmol, 1.0 equiv.) was added to a $250 \mathrm{~mL} \mathrm{RBF}$ followed by $\mathrm{MeOH}(50 \mathrm{~mL})$. Then, ethyl trifluoroacetate $(5.5 \mathrm{~mL}, 45.9 \mathrm{mmol}, 1.05$ equiv.) in $\mathrm{MeOH}(20 \mathrm{~mL})$ was added dropwise to the reaction solution. The solution was stirred for $3 \mathrm{~h}$ and concentrated on a rotary evaporator. The resulting oil was taken up in EtOAc $(150 \mathrm{~mL})$ and was washed with $0.5 \mathrm{M} \mathrm{KHSO}_{4}(50 \mathrm{~mL} \times 2)$ and saturated $\mathrm{NaCl}(50 \mathrm{~mL})$. The organic layer was dried over $\mathrm{Na}_{2} \mathrm{SO}_{4}$, filtrated, and concentrated on a rotary evaporator. The resulting oil became a faint yellow crystal after drying under vacuum to give a $11.8 \mathrm{~g}$ (93\%) of $\mathbf{1 5}$. Rf: 0.46 (Hexane/EtOAc=2:1); mp: $94-95{ }^{\circ} \mathrm{C} ;{ }^{1} \mathbf{H}$ NMR: $\delta\left(300 \mathrm{MHz}, \mathrm{CDCl}_{3}\right) 8.09(1 \mathrm{H}$, 
bs, NH), $7.49(1 \mathrm{H}, \mathrm{d}, J=8.4 \mathrm{~Hz}, \operatorname{Ar}), 7.39(1 \mathrm{H}, \mathrm{d}, J=1.8 \mathrm{~Hz}, \operatorname{Ar}), 7.12(1 \mathrm{H}, \mathrm{dd}, J=$ 8.4, $1.8 \mathrm{~Hz}$, inC $\left._{5} \mathbf{H}\right), 7.02\left(1 \mathrm{H}, \mathrm{s}, \mathrm{inC}_{2} \mathbf{H}\right), 6.33\left(1 \mathrm{H}, \mathrm{bs}, \mathrm{NHCOCF}_{3}\right), 3.68(2 \mathrm{H}, \mathrm{q}, J=6.6$ $\left.\mathrm{Hz}, \mathrm{CH}_{2} \mathrm{~N}\right), 3.03\left(2 \mathrm{H}, \mathrm{t}, J=6.6 \mathrm{~Hz}, \mathrm{CH}_{2} \mathrm{CH}_{2} \mathrm{~N}\right) ;{ }^{13} \mathbf{C}$ NMR: $\delta\left(75 \mathrm{MHz}, \mathrm{CDCl}_{3}\right): 157.5$ (q, $\mathrm{J}=37.2 \mathrm{~Hz}$ ), 137.0, 128.6, 125.8, 123.0, 120.7, 119.5, 116.0 (q, J = 288.0), 112.2, 111.6; LRMS (ESI-MS m/z): Calcd for $\mathrm{C}_{12} \mathrm{H}_{11} \mathrm{ClF}_{3} \mathrm{~N}_{2} \mathrm{O}[\mathrm{M}+\mathrm{H}]^{+}=291.0$; Found 291.0

$N$-Trifluoroacetyl- $N^{\text {in }}$-Boc-6-Chlorotryptamine $\quad(16) \quad: \quad N$-Trifluoroacetyl-6Chlorotryptamine 15 (10.8 g, $37 \mathrm{mmol}, 1$ equiv.) was added to a $250 \mathrm{~mL}$ RBF followed by DCM $(100 \mathrm{~mL})$. The resulting solution was was warmed to $35{ }^{\circ} \mathrm{C}$ via a oil bath. Next, (Boc) $)_{2} \mathrm{O}$ (8.71 g, $40.7 \mathrm{mmol}, 1.1$ equiv.) and DMAP (452 mg, $3.7 \mathrm{mmol}, 0.1$ equiv.) were added to the reaction flask. The solution was stirred for $1 \mathrm{~h}$ at $35^{\circ} \mathrm{C}$ and was transferred to a separatory funnel with DCM $(250 \mathrm{~mL})$. The organic layer was washed with $0.5 \mathrm{M} \mathrm{KHSO}_{4}(50 \mathrm{~mL} \times 2)$, saturated $\mathrm{NaCl}(50 \mathrm{~mL}), 0.5 \mathrm{M} \mathrm{NaHCO}_{3}(50 \mathrm{~mL}$ $x$ 2) and saturated $\mathrm{NaCl}(50 \mathrm{~mL})$. The organic layer was dried over $\mathrm{Na}_{2} \mathrm{SO}_{4}$, filtered, and concentrated using a rotary evaporator to give a crude oil. The oil was purified by flash column chromatography (Hexane/EtOAc=5:1 then 5:2) to give $9.4 \mathrm{~g}(65 \%)$ of 16 as a viscous, faint yellow oil. The oil became an off-white crystal after drying under vacuum. Rf: 0.29 (Hexane/EtOAc=5:1); mp: $103-104{ }^{\circ} \mathrm{C} ;{ }^{1} \mathbf{H}$ NMR: $\delta\left(300 \mathrm{MHz}, d_{6}\right.$-DMSO): $9.54\left(1 \mathrm{H}\right.$, br t $\left., J=5.7 \mathrm{~Hz}, \mathrm{NHCOCF}_{3}\right), 8.05(1 \mathrm{H}, \mathrm{d}, J=1.8 \mathrm{~Hz}, \mathrm{Ar}), 7.65(1 \mathrm{H}, \mathrm{d}, J=8.1$ $\mathrm{Hz}, \mathrm{Ar}), 7.53\left(1 \mathrm{H}, \mathrm{s}, \mathrm{inC}_{2} \mathbf{H}\right), 7.32(1 \mathrm{H}, \mathrm{dd}, J=8.1,1.8 \mathrm{~Hz}, \mathrm{Ar}), 3.47(2 \mathrm{H}, \mathrm{q}, J=6.9 \mathrm{~Hz}$, $\left.\mathrm{CH}_{2} \mathrm{~N}\right), 2.90\left(2 \mathrm{H}, \mathrm{t}, J=6.9 \mathrm{~Hz}, \mathrm{CH}_{2} \mathrm{CH}_{2} \mathrm{~N}\right) ;{ }^{13} \mathbf{C ~ N M R : ~} \delta\left(75 \mathrm{MHz}, \mathrm{CDCl}_{3}\right): 157.5(\mathrm{q}, J=$ $37.0 \mathrm{~Hz}), 149.4,136.2,131.0,128.6,124.0,123.5,119.5,116.5,116.0,116.0$ (q, J = $287.8 \mathrm{~Hz}), 84.6,39.8,28.3,24.6$

$N^{\text {in }}$-Boc-6-Chlorotryptamine hydrochloride (17) : $N$-Trifluoroacetyl- $N^{\text {in }}$-Boc-6Chlorotryptamine 16 (1.82 g, $4.46 \mathrm{mmol}, 1$ equiv.) was added to a Schlenk tube that contained a 7M solution of $\mathrm{NH}_{3}$ in $\mathrm{MeOH}$ (168 mL, $1.16 \mathrm{mmol}, 250$ equiv.). The screwcap was placed on tightly and the reaction was stired for 2 days at $\mathrm{rt}$. The solvent was evaporated with a steady steam of $\mathrm{N}_{2}(\mathrm{~g})$ over $2 \mathrm{~h}$. The remaining residue was taken up in EtOAc $(100 \mathrm{~mL})$ and $1 \mathrm{M} \mathrm{HCl}(50 \mathrm{~mL})$ was added. The mixture was filtered with a glass fritted funnel and washed with diethyl ether $(50 \mathrm{~mL} \times 2)$. The salt was dried under vacuum to give $382 \mathrm{mg}(25 \%)$ of $\mathbf{1 7}$ as a white solid. Rf: 0.40 $\left(\mathrm{CHCl}_{3} / \mathrm{MeOH} / \mathrm{AcOH}=80: 20: 1\right)$; mp: $208{ }^{\circ} \mathrm{C}(\mathrm{dec}) ;{ }^{1} \mathbf{H}$ NMR: $\delta\left(300 \mathrm{MHz}, d_{6}\right.$-DMSO): $8.06(1 \mathrm{H}, \mathrm{d}, J=1.5 \mathrm{~Hz}, \mathrm{Ar}), 7.98\left(3 \mathrm{H}, \mathrm{bs}, \mathrm{NH}_{2}\right), 7.71(1 \mathrm{H}, \mathrm{d}, J=8.1 \mathrm{~Hz}, \operatorname{Ar}), 7.64(1 \mathrm{H}, \mathrm{s}$, inC $\left._{2} \mathbf{H}\right), 7.32(1 \mathrm{H}, \mathrm{dd}, J=8.4,1.8 \mathrm{~Hz}, \mathrm{Ar}), 3.11-3.08\left(2 \mathrm{H}, \mathrm{m}, \mathrm{CH}_{2} \mathrm{~N}\right), 3.01-2.97(2 \mathrm{H}, \mathrm{m}$, $\left.\mathrm{CH}_{2} \mathrm{CH}_{2} \mathrm{~N}\right) ;{ }^{13} \mathbf{C}$ NMR: $\delta\left(75 \mathrm{MHz}, d_{6}\right.$-DMSO) $148.7,135.2,129.2,128.7,124.9,122.8$, 120.7, 116.0, 114.6, 84.4, 38.3, 27.6, 22.4; LRMS (ESI-MS m/z): Calcd for $\mathrm{C}_{15} \mathrm{H}_{20} \mathrm{ClN}_{2} \mathrm{O}_{2}[\mathrm{M}+\mathrm{H}]^{+}=295.5$; Found 295.1

$N^{i n}$-Boc-tryptamine (18) was prepared according to the procedure described by Uno and coworkers. ${ }^{6}$ Rf: 0.21 $\left(\mathrm{CHCl}_{3} / \mathrm{MeOH} / \mathrm{AcOH}=80: 20: 2\right) ;{ }^{1} \mathrm{H} \mathrm{NMR}$ data were consistent with the literature value for this compound.

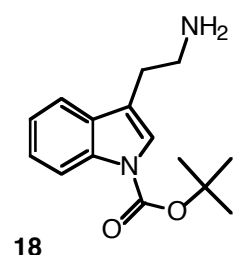




\section{Scheme 4}

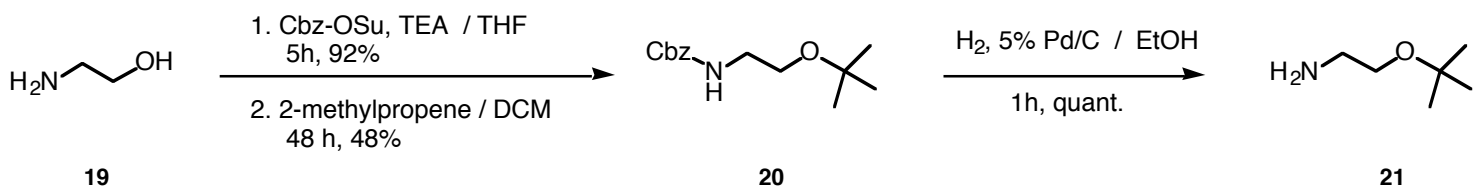

$\boldsymbol{N}$-Cbz-O-tert-butyl-ethanolamine (20) : $\mathrm{N}$-Cbz-ethanolamine (7.8 g, $40 \mathrm{mmol})$ was added to a Schlenk tube followed by DCM $(100 \mathrm{~mL})$, conc. $\mathrm{H}_{2} \mathrm{SO}_{4}(0.5 \mathrm{~mL})$ and cooled in an ice/water bath. Next, 2-methylpropene $(130 \mathrm{~mL}$, ca. $1.6 \mathrm{~mol})$ was added via cannula and the tube was sealed for 3 days at rt. The mixture was coold again to $0{ }^{\circ} \mathrm{C}$ via an ice/water bath, then excess 2-methylpropene was evaporated with a steady steam of $\mathrm{N}_{2}$ (g) over $1 \mathrm{~h}$. The remaining solution was neutralized with TEA and was evaporated in vacuo. The residue was taken up in EtOAc $(100 \mathrm{~mL})$ and was washed with $0.5 \mathrm{M}$ $\mathrm{KHSO}_{4}(50 \mathrm{~mL} \times 2), 0.5 \mathrm{M} \mathrm{NaHCO}_{3}(50 \mathrm{~mL} \times 2)$ and saturated $\mathrm{NaCl}(50 \mathrm{~mL})$. The organic layer was dried over $\mathrm{Na}_{2} \mathrm{SO}_{4}$, then concentrated to give a crude oil which was purified by silica gel column chromatography (Hexanes/EtOAc $=5 / 1.5$ then $5 / 3$ ) to give $4.8 \mathrm{~g}$ (19 mmol, $48 \%$ yield) of $\mathbf{2 0}$ as a colorless oil. Rf: 0.53 (Hexanes/EtOAc $=5 / 3$ ); ${ }^{1} \mathbf{H}$ NMR: $\delta\left(300 \mathrm{MHz}, \mathrm{CDCl}_{3}\right)$ 7.37-7.31 (5H, m, Ar), 5.11 (2H, s, PhCH $), 3.44-3.41(2 \mathrm{H}$, $\left.\mathrm{m}, \mathrm{OCH}_{2}\right), 3.36-3.31\left(2 \mathrm{H}, \mathrm{m}, \mathrm{NCH}_{2}\right), 1.17(9 \mathrm{H}, \mathrm{s}, t$-Bu-CH$) ;{ }^{13} \mathbf{C} \mathbf{N M R}: \delta(75 \mathrm{MHz}$, $\mathrm{CDCl}_{3}$ ) 156.7, 136.9, 128.7, 128.3 (broad, overlaped 2 peaks), 73.3, 66.9, 60.7, 41.8, 27.7; LRMS (ESI-MS m/z): Calcd for $\mathrm{C}_{14} \mathrm{H}_{22} \mathrm{NO}_{3}[\mathrm{M}+\mathrm{H}]^{+}=252.2, \mathrm{C}_{10} \mathrm{H}_{14} \mathrm{NO}_{3}$ [M-tert$\mathrm{Bu}+\mathrm{H}]^{+}=196.2$ and $\mathrm{C}_{8} \mathrm{H}_{10} \mathrm{NO}_{2}\left[\mathrm{M}-\left(\mathrm{CH}_{2} \mathrm{CH}_{2} \mathrm{O} \text {-tert-Bu)+H}\right]^{+}=152.1\right.$; Found 252.0 (20 $\%), 196.0$ (base peak) and $152.0(50 \%)$

O-tert-Butyl-ethanolamine (21) : $\mathrm{N}$-Cbz-O-tert-butyl-ethanolamine (20) $(6 \mathrm{~g}, 23.9$ $\mathrm{mmol})$ was added to a $250 \mathrm{~mL} \mathrm{RBF}$ followed by $\mathrm{EtOH}(100 \mathrm{~mL}) .5 \% \mathrm{Pd} / \mathrm{C}(0.8 \mathrm{~g})$ was added to the reaction mixture, then hydrogen is introduced to the solution by a gas inlet tube with stirring for $1 \mathrm{~h}$. The reaction mixture was filtered, and concentrated on a rotary evaporator to give $2.7 \mathrm{~g}(23 \mathrm{mmol}, 96 \%)$ of 21 as a colorless oil. Rf: 0.48 $\left(\mathrm{CHCl}_{3} / \mathrm{MeOH} / \mathrm{AcOH}=80: 20: 1\right) ;{ }^{1} \mathbf{H}$ NMR: $\delta\left(300 \mathrm{MHz}, d_{6}\right.$-DMSO) $3.26(2 \mathrm{H}, \mathrm{t}, J=5.7$ $\left.\mathrm{Hz}, \mathrm{OCH}_{2}\right), 2.60\left(2 \mathrm{H}, \mathrm{t}, J=5.7 \mathrm{~Hz}, \mathrm{NCH}_{2}\right), 1.12\left(9 \mathrm{H}, \mathrm{s}, t-\mathrm{Bu}-\mathrm{CH}_{3}\right) ;{ }^{13} \mathbf{C} \mathbf{N M R}: \delta(75$ $\mathrm{MHz}, d_{6}$-DMSO) 72.1, 63.2, 42.0, 27.4. 


\section{Peptoid synthesis and characterization}

\section{Scheme 5}

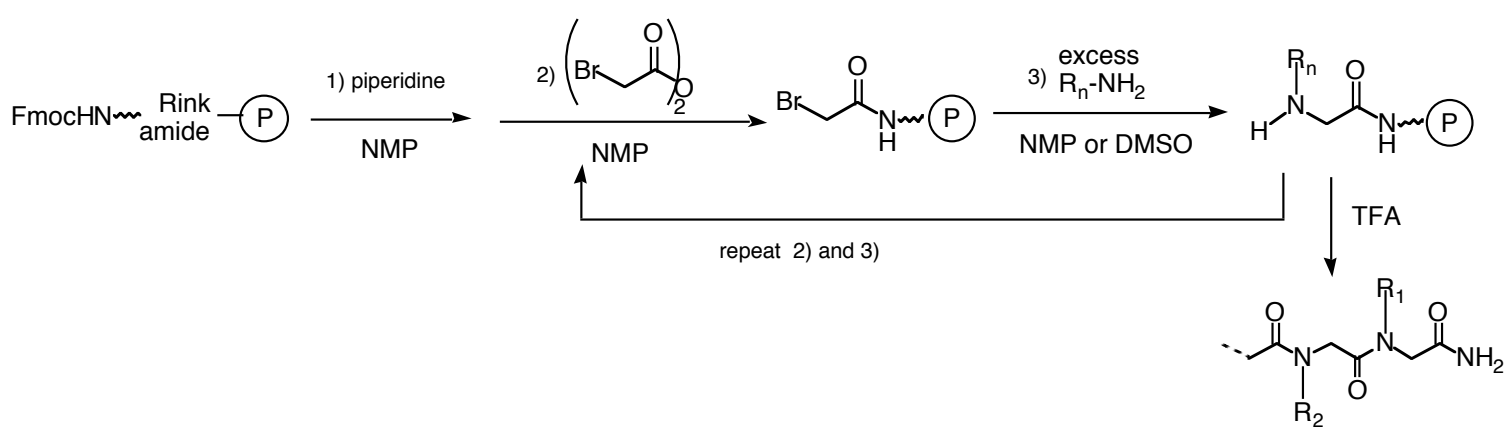

\section{Peptoid synthesis}

All peptoids were synthesized manually using a modification of the submonomer methodology developed by Zuckerman and coworkers (scheme 5). ${ }^{7}$ Typically, $143 \mathrm{mg}$ of Rink amide TentaGel resin $(0.04 \mathrm{mmol}, 1$ equiv., $0.28 \mathrm{mmol} / \mathrm{g})$ was added to a fritted polypropylene tube (Piece, Rockford, IL, product\# 29924) followed by NMP (3 mL), and was swelled for 30 min with agitation. Next, the Fmoc protecting group was removed by treatment with $20 \%$ piperdine $(1.5 \mathrm{~mL})$ in NMP for $10 \mathrm{~min}$. The resin was washed with NMP $(1.5 \mathrm{~mL} \times 8)$. Then, the amine on solid phase was bromoacetylated with $0.6 \mathrm{M}$ solution of bromoacetic anhydride in NMP ( $1 \mathrm{~mL}, 0.6 \mathrm{mmol}, 15$ equiv.). The reaction was agitated for $40 \mathrm{~min}$ at $\mathrm{rt}$. This acylation step was repeated once. The resin was rinsed with NMP (1.5 mL $\times 8$ ) to remove excess reagent. Then, displacement reactions were performed by addition of appropriate primary amines ( $1 \mathrm{mmol}, 25$ equiv.) as 1.0-1.5 $\mathrm{M}$ solution in either NMP or DMSO, followed by agitation for $2.5 \mathrm{~h}$ at $\mathrm{rt}$. The resin was washed with NMP $(1.5 \mathrm{~mL} \times 8)$ to remove excess reagent. Peptoids were elongated by successive repetition of the above two steps until the desired sequence was obtained.

Removal of the side-chain protecting groups and cleavage of the peptoid form the resin were accomplished by treatment with TFA/thioanisole/1,2-ethanedithiol/water = 80:2.5:5:12.5 (v/v/v/v) $(1.5 \mathrm{~mL}$ per $100 \mathrm{mg}$ resin) for $1.5 \mathrm{~h}$ at $\mathrm{rt}$. The resultant solution was concentrated under a steady steam of $\mathrm{N}_{2}(\mathrm{~g})$. The residue was precipitated with diethyl ether and was washed with diethyl ether 2 times.

The crude products were analyzed and purified by reverse-phase HPLC with UV detection at $214 \mathrm{~nm}$ (Hewlett Packard series 1050 or 1100, Agilent Technologies, Palo Alto, CA, USA). VYDAK C4 ( $\mathrm{d}=4.5 \mathrm{~mm}, \mathrm{l}=250 \mathrm{~mm}, 5$ microns; $\mathrm{d}=20 \mathrm{~mm}, 1=250 \mathrm{~mm}, 10$ microns) columns were utilized, eluting with $0.05 \%$ TFA in water (Solution A) and $0.04 \%$ TFA in $\mathrm{CH}_{3} \mathrm{CN}$ (Solution B). Peptoids were characterized by MALDI-TOF MS. All peptoids gave molecular ions consistent with the final product. The yields of the final products ranged from 10 to $30 \%$, based on the content of Fmoc group in the starting resin. 
Table 1. MALDI-TOF MS analysis of peptoids

\begin{tabular}{|c|c|c|c|}
\hline peptoids & $\begin{array}{l}\text { formular } \\
\qquad[\mathrm{M}]\end{array}$ & $\begin{array}{l}\text { mass calcd. } \\
{[\mathrm{M}-\mathrm{H}]^{-}}\end{array}$ & $\begin{array}{l}\text { mass found } \\
{[\mathrm{M}-\mathrm{H}]^{-}}\end{array}$ \\
\hline 1 & $\mathrm{C}_{84} \mathrm{H}_{104} \mathrm{~N}_{12} \mathrm{O}_{16}$ & 1535.77 & 1535.52 \\
\hline 2 & $\mathrm{C}_{84} \mathrm{H}_{113} \mathrm{~N}_{12} \mathrm{O}_{19} \mathrm{P}_{3}$ & 1685.75 & 1685.82 \\
\hline 3 & $\mathrm{C}_{84} \mathrm{H}_{109} \mathrm{~N}_{16} \mathrm{O}_{27} \mathrm{P}_{3}$ & 1865.69 & 1865.79 \\
\hline 4 & $\mathrm{C}_{84} \mathrm{H}_{109} \mathrm{~N}_{17} \mathrm{O}_{26} \mathrm{P}_{2} \mathrm{~S}$ & 1864.69 & 1864.29 \\
\hline 5 & $\mathrm{C}_{77} \mathrm{H}_{103} \mathrm{~N}_{17} \mathrm{O}_{26} \mathrm{P}_{2} \mathrm{~S}$ & 1774.65 & 1774.77 \\
\hline 6 & $\mathrm{C}_{75} \mathrm{H}_{102} \mathrm{~N}_{16} \mathrm{O}_{26} \mathrm{P}_{2} \mathrm{~S}$ & 1735.63 & 1735.56 \\
\hline 7 & $\mathrm{C}_{80} \mathrm{H}_{101} \mathrm{~N}_{17} \mathrm{O}_{26} \mathrm{P}_{2} \mathrm{~S}$ & 1808.63 & 1808.59 \\
\hline 8 & $\mathrm{C}_{84} \mathrm{H}_{109} \mathrm{~N}_{17} \mathrm{O}_{26} \mathrm{P}_{2} \mathrm{~S}$ & 1864.69 & 1864.32 \\
\hline 9 & $\mathrm{C}_{84} \mathrm{H}_{109} \mathrm{~N}_{17} \mathrm{O}_{26} \mathrm{P}_{2} \mathrm{~S}$ & 1864.69 & 1864.49 \\
\hline 10 & $\mathrm{C}_{84} \mathrm{H}_{108} \mathrm{ClN}_{17} \mathrm{O}_{26} \mathrm{P}_{2} \mathrm{~S}$ & 1898.65 & 1898.67 \\
\hline 11 & $\mathrm{C}_{84} \mathrm{H}_{109} \mathrm{~N}_{17} \mathrm{O}_{26} \mathrm{P}_{2} \mathrm{~S}$ & 1864.69 & 1864.56 \\
\hline 12 & $\mathrm{C}_{80} \mathrm{H}_{101} \mathrm{~N}_{17} \mathrm{O}_{26} \mathrm{P}_{2} \mathrm{~S}$ & 1808.64 & 1808.15 \\
\hline 13 & $\mathrm{C}_{80} \mathrm{H}_{100} \mathrm{ClN}_{17} \mathrm{O}_{26} \mathrm{P}_{2} \mathrm{~S}$ & 1842.59 & 1842.46 \\
\hline \multirow[t]{2}{*}{14} & $\mathrm{C}_{75} \mathrm{H}_{99} \mathrm{ClN}_{16} \mathrm{O}_{25} \mathrm{P}_{2} \mathrm{~S}$ & 1751.59 & 1751.63 \\
\hline & & {$[\mathrm{M}+\mathrm{H}]^{+}$} & {$[\mathrm{M}+\mathrm{Na}]^{+}$} \\
\hline PS1 & $\mathrm{C}_{100} \mathrm{H}_{113} \mathrm{~N}_{11} \mathrm{O}_{10}$ & 1628.87 & 1650.48 \\
\hline \multirow[t]{2}{*}{ PS2 } & $\mathrm{C}_{99} \mathrm{H}_{116} \mathrm{~N}_{12} \mathrm{O}_{10}$ & 1633.89 & 1656.52 \\
\hline & & {$[\mathrm{M}-\mathrm{H}]^{-}$} & {$[\mathrm{M}-\mathrm{H}]^{-}$} \\
\hline PS3 & $\mathrm{C}_{82} \mathrm{H}_{105} \mathrm{~N}_{18} \mathrm{O}_{25} \mathrm{PS}_{2}$ & 1835.67 & 1835.27 \\
\hline PS4 & $\mathrm{C}_{84} \mathrm{H}_{108} \mathrm{~N}_{17} \mathrm{O}_{25} \mathrm{PS}_{2}$ & 1848.69 & 1848.60 \\
\hline PS5 & $\mathrm{C}_{94} \mathrm{H}_{119} \mathrm{~N}_{19} \mathrm{O}_{29} \mathrm{P}_{2} \mathrm{~S}$ & 2070.76 & 2070.08 \\
\hline PS6 & $\mathrm{C}_{94} \mathrm{H}_{119} \mathrm{~N}_{19} \mathrm{O}_{29} \mathrm{P}_{2} \mathrm{~S}$ & 2070.76 & 2070.52 \\
\hline PS7 & $\mathrm{C}_{64} \mathrm{H}_{89} \mathrm{~N}_{13} \mathrm{O}_{20} \mathrm{P}_{2} \mathrm{~S}$ & 1452.55 & 1453.23 \\
\hline
\end{tabular}




\section{HDM2 Preparation, CD, Fluorescence polarization Competition and ITC binding study}

\section{HDM2 Preparation ${ }^{1,8}$}

The His-tagged N-terminal domain of HDM2, corresponding to amino acids 1-125, was overexpressed in BL21(DE3)pLysS cells at $30^{\circ} \mathrm{C}$. The cells were lysed by sonication, and the supernatant was applied to a TALON metal affinity column (Clontech, Palo Alto, CA). The partly purified HDM2 fragment was further purified using a 16/60 Superdex 75 column (Amersham Biosciences, Piscataway, NJ) that was equilibrated with PBS buffer. The purified HDM2 was $>95 \%$ pure as assessed by PAGE analysis, and was stored at -78 ${ }^{\circ} \mathrm{C}$. The concentrations of the HDM2 solutions were determined by $\mathrm{A}_{280}$.

\section{FP competition assay ${ }^{1}$}

In a glass cuvette (PanVera-Invitrogen), a solution HDM2(1-125) (final concentration 2.2 $\mu \mathrm{M})$ and Flu-p53(15-29) (30nM final concentration) was prepared in Tris $\mathrm{HCl}$ buffer $\mathrm{pH}$ 7.6, and these mixtures were titrated with the competitor. Final samples were in $10 \mathrm{mM}$ Tris $\mathrm{HCl}, 150 \mathrm{mM} \mathrm{NaCl}, 2 \mathrm{mM} \beta$-melcaptethanol, $0.5 \mathrm{mM}$ EDTA, $0.1 \mathrm{mg} / \mathrm{ml} \mathrm{BSA}, \mathrm{pH}=$ 7.6. After each addition, the solution was incubated at $\mathrm{rt}$ for $30 \mathrm{~min}$ prior to data acquisition. Fluorescence anisotropy was measured in a PanVera Beacon 2000 instrument (PanVera-Invitrogen) at $25{ }^{\circ} \mathrm{C}$. Data points were determined in duplicate or triplicate and error bars indicate standard deviation. $\mathrm{IC}_{50}$ values were calculated by nonlinear regression curve fitting with a one-site competition model $: \mathrm{mP}_{\mathrm{obs}}=\mathrm{mP}_{\min }+$ $\left(\left(\mathrm{mP}_{\max }-\mathrm{mP}_{\min }\right) /\left(1+10^{\wedge}\right.\right.$ ([competitor $\left.\left.]-\mathrm{IC}_{50}\right)\right)$ using GraphPad Prism 4.0 software.

\section{Isothermal Titration Calorimetry}

ITC measurements were performed using a VP-ITC calorimeter (MicroCal, Northhampton, MA). Titrations were performed in $10 \mathrm{mM}$ Tris $\mathrm{HCl}, 150 \mathrm{mM} \mathrm{NaCl}, 1 \mathrm{mM} \beta$ melcaptethanol, $\mathrm{pH}$ 7.6. The protein and peptide solutions were degassed before each experiment. Heats of dilution were subtracted from the raw data. The values for the stoichiometry of binding and thermodynamic constants were determined using the ORIGIN software package provided by the VP-ITC calorimeter manufacturer as described previously. ${ }^{9}$ The reported $\Delta \mathrm{S}, \Delta \mathrm{H}, \Delta \mathrm{G}$ and $\mathrm{K}_{\mathrm{d}}$ values are the average of two or three independent experiment.

\section{Measurements}

CD spectra were measured on a Jasco J-715 apparatus using a 1-mm path length quartz cell at room temperature. The instrumental outputs were calibrated with nonhygroscopic ammonium $d$-camphor-10-sulfonate. ${ }^{10}$ Eight scans were averaged for each sample, and the average blank spectra were subtracted. Mean residue ellipticity $[\theta]\left(\mathrm{deg} \mathrm{cm} \mathrm{dmol}^{-1}\right)$ was obtained using the equation :

$$
[\theta]=100 \times \theta_{\text {obs }} / \mathrm{n} \times 1 \times \mathrm{c}
$$

where $\theta_{\mathrm{obs}}$ is measured ellipticity in millidegrees, $\mathrm{n}$ is the number of residues, 1 is path length in centimeter, and $\mathrm{c}$ is the concentration of peptoids in millimolar. The reported 
spectra are the average of two or three independent experiment. Errors reflect standard deviations of the mean.

\title{
References
}

1. Sakaguchi, K.; Saito, S.; Higashimoto, Y.; Roy, S.; Anderson, C. W. and Appella, E. J. Biol. Chem. 2000, 275, 9278-9283.

2. Brouwer, A. J.; Monnee, M. C. F. and Liskamp, R. M. J. Synthesis 2000, 11, 15791584.

3. Bako, P.; Novak, T.; Ludanyi, K.; Pete, B.; Toke, L. and Keglevich, G. Tetrahedron: Asymmetry. 1999, 10, 2373-2380.

4. Armstrong, A.; Brackenridge, I.; Jackson, R. F. W. and Kirk, J. M. Terahedron Lett. 1988, 29, 2483-2486.

5. Whittle, B. A. and Young, E. H. P. J. Med. Chem. 1963, 6, 378-380.

6. Uno, T.; Beausoleil, E.; Glodsmith, R. A.; Levine, B. H. and Zuckermann, R. N. Terahedron Lett. 1999, 40, 1475-1478.

7. Figliozzi, G. M.; Goldsmith, R.; Ng, S. C.; Banville, S. C. and Zuckermann, R. N. Methods Enzymol. 1996, 267, 437-447.

8. Kussie, P.H.; Gorina, S.; Marechal, V.; Elenbaas, B.; Moreau, J.; Levine, A. J.; Pavletich, N. P. Science, 1996, 274, 921-922.

9. Houtman, J.C.D.; Higashimoto, Y.; Dimasi, N.; Cho, S.W.; Yamaguchi, H.; Bowden, B.; Regan, C.; Malchiodi, E. L.; Mariuzza, R.; Schuck, P.; Appella, E. and Samelson, L. E. Biochemistry 2004, 43, 4170-4178

10. Takakuwa, T.; Konno, T. and Meguro, H. Anal. Sci. 1985, 1, 215-218.

\author{
Appendix: \\ EQUILIBRIUM ULTRACENTRIFUGAL ANALYSIS OF Peptoid 13 \\ Marc S. Lewis \\ Molecular Interactions Resource \\ Division of Biomedical Engineering and Physical Science \\ Office of Research Services
}

\section{Experimental:}

180 microliter samples of Peptoid 13 at concentrations of 4.1, 6.8, and 9.5 micromolar, respectively, were loaded in centrifuge cells with $12 \mathrm{~mm}$ optical path length carbon-filled epon double-sector centerpieces and were run at an initial speed of $42,000 \mathrm{rev} / \mathrm{min}$ at a temperature of $20.0{ }^{\circ} \mathrm{C}$ in a Beckman-Coulter XL-A analytical ultracentrifuge. The buffer used was $10 \mathrm{mM}$ Tris (pH 7.6), $150 \mathrm{mM} \mathrm{NaCl}$, and $5 \mathrm{mM}$ EDTA. The buffer density of $1.002265 \mathrm{gm} \mathrm{cm}^{-3}$ at $20.000{ }^{\circ} \mathrm{C}$ was measured in an Anton Paar DMA 5000 Density Meter. All scans were taken at a wavelength of $278 \mathrm{~nm}$, the center of a broad 
spectral peak. 10 replicates were taken at each radial position and the radial increments were $0.001 \mathrm{~cm}$. Final scans at the rotor speed of 42,000 rev/min were taken at 47 hours after ensuring that equilibrium had been attained. The rotor speed was then increased to $50,000 \mathrm{rev} / \mathrm{min}$ for an additional 28 hours for the equilibrium scans at that rotor speed. The best quality scans were obtained with the highest concentration, which was the only concentration deemed optimal for data analysis. Data at two rotor speeds is considered sufficient for good global analysis of a simple system of this type.

\section{Data Analysis:}

Since the objective of this study was to determine whether Peptoid 13 was monomeric or if it also existed in a reversible or irreversible oligomeric form, the data from the two rotor speeds was initially globally fit with a pair of equations describing an ideal monomeric species. Such a mathematical model has the form:

$$
c_{i}(r)=c_{i, b} \exp \left((1-\bar{v} \rho) \omega_{i}^{2} / 2 R T\right) M\left(r^{2}-r_{b}^{2}\right)+\varepsilon_{i}
$$

where the subscript $i$ refers to the rotor speed; $c$, which is a function of radius, $r$, is expressed as absorbance at $278 \mathrm{~nm}$; the subscript $b$ refers to the radial position of the cell bottom, which is taken as a reference position; $\bar{v}$ is the partial specific volume of the solute in $\mathrm{cm}^{3} \mathrm{~g}^{-1} ; \rho$ is the density of the solvent in $\mathrm{gm} \mathrm{cm}^{-3}$; $\omega$ is the angular velocity of the rotor in radians $\left.\sec ^{-1}(2 \pi \mathrm{rpm} / 60)\right) ; R$ is the gas constant $\left(8.314 \times 10^{7} \mathrm{ergs} \mathrm{K}^{-1} \mathrm{~mol}^{-1}\right.$ \}, $T$ is the absolute temperature $(293.15 \mathrm{~K}) ; M$ is the molar mass of the solute $(1843.59 \mathrm{~g}$ $\mathrm{mol}^{-1}$ ), and $\varepsilon$ is the baseline error term. For the global fitting at two rotor speeds, $\bar{v}$ is a global fitting parameter and the values of $\mathrm{c}_{\mathrm{i}, \mathrm{b}}$ and $\varepsilon_{\mathrm{i}}$ are local, speed-dependent parameters.

Because absorbance data does not have normally distributed error, but instead has a logarithmically skewed Cauchy-type error distribution, the two data sets were fit using non-linear L-1 (robust) regression rather than the usual non-linear least squares (L-2) regression. ${ }^{1,2}$ The difference between these is that while L-2 regression minimizes the sum of the squares of the residuals, L-1 regression minimizes the sum of their absolute values and has been demonstrated to be mathematically more appropriate for nonGaussian error distributions since a principal requisite for the application of L-2 regression is that the error distribution must be Gaussian. Since the value of the molar mass is known in this analysis, the partial specific volume was the global parameter of interest.

\section{Results and Discussion:}

Graphs of the fits of the single component models to the concentration distributions, as shown in Figure 1, were excellent. This was further substantiated by plots of the residuals, Figure 2, that did not demonstrate any systematic deviations which could possibly be indicative of any degree of heterogeneity due to the presence of dimer or higher oligomers either in reversible equilibrium or in irreversible aggregation. There is 
no evidence that could lead to the conclusion that there might be any species other than monomer present. The value of the partial specific volume at $20.0{ }^{\circ} \mathrm{C}$ from the global analysis was $0.6287 \pm 4.819 \times 10^{-5} \mathrm{~cm}^{3} \mathrm{~g}^{-1}$. The mean of the absolute values of the residuals was $2.62 \times 10^{-3}$ absorbance units, indicating a joint fit of excellent quality, in substantiation of the conclusions cited above.

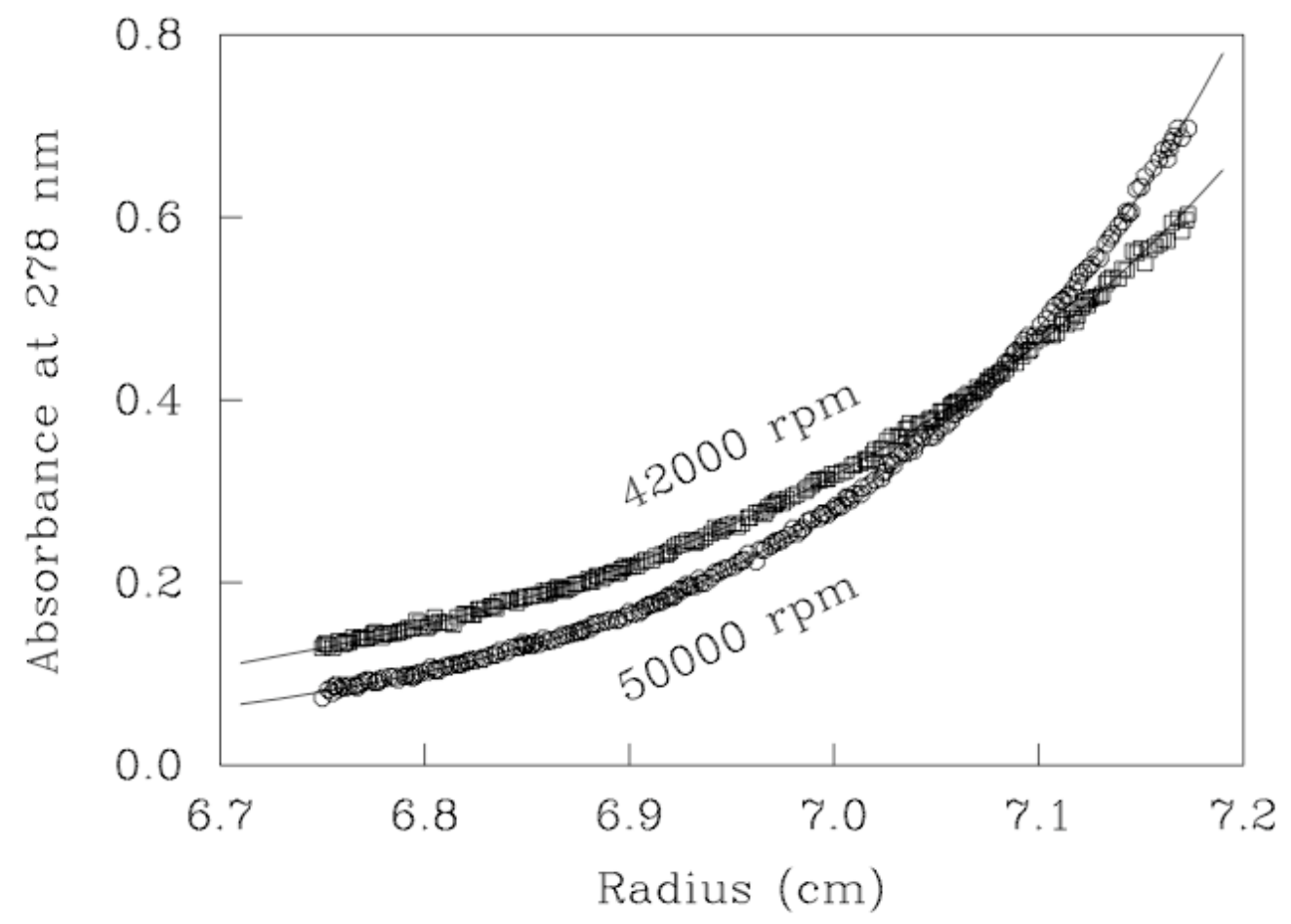

Figure 1. . Distribution of Peptoid 13 at equilibrium at $42,000 \mathrm{rev} / \mathrm{min}$ (squares) and $50,000 \mathrm{rev} / \mathrm{min}$ (circles) scanned at a wavelength of $278 \mathrm{~nm}$ and fit jointly. 

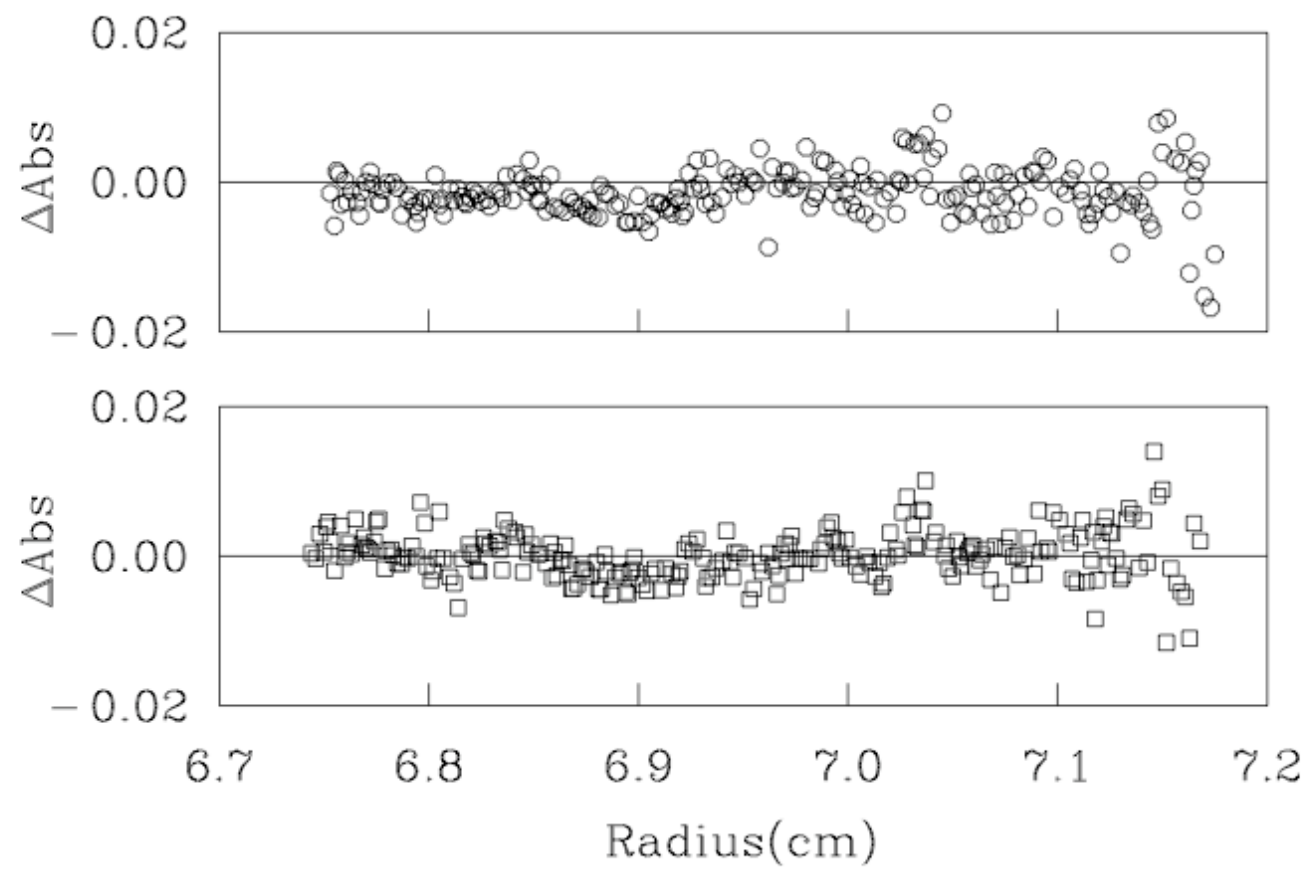

Figure 2. . Distribution of the residuals of the joint fits shown in Figure 1.. The upper panel is for the fit of the $50,000 \mathrm{rev} / \mathrm{min}$ data; the lower panel is for the $42,000 \mathrm{rev} / \mathrm{min}$ data.

\section{References:}

1. Lewis, M. S.; Reily, M. M. Methods in Enzymology. Johnson, M and Brand, L., Eds., Academic Press, San Diego, 384: 232-242, 2004

2. Lewis, M. S. and Reily, M. M.: In Analytical Ultracentrifugation: Techniques and Methods. Scott, D. J., Harding, S. E. and Rowe, A. T., Eds. Royal Society of Chemistry, London. 151-162, 2005. 